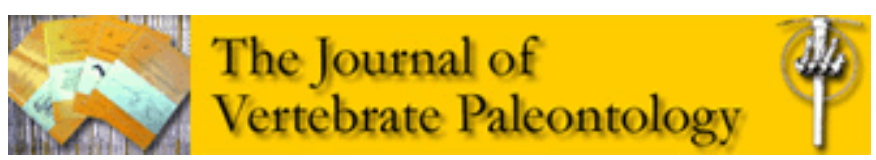

\title{
Tristichopterids (Sarcopterygii, Tetrapodomorpha) from the Late Devonian tetrapod-bearing locality of Strud (Belgium, late Famennian), with phylogenetic and paleobiogeographic considerations
}

\begin{tabular}{|r|l|}
\hline Journal: & Journal of Vertebrate Paleontology \\
\hline Manuscript ID & Draft \\
\hline Manuscript Type: & Article \\
\hline Date Submitted by the & $\mathrm{n} / \mathrm{a}$ \\
\hline Complete List of Authors: & $\begin{array}{l}\text { Olive, Sébastien; Royal Belgian Institute of Natural Sciences, } \\
\text { Paleontology } \\
\text { Leroy, Yann; Royal Belgian Institute of Natural Sciences, Paleontology } \\
\text { Daeschler, Edward; Academy of Natural Sciences, Department of } \\
\text { Vertebrate Paleontology } \\
\text { Downs, Jason; Delaware Valley University, Biology; Academy of Natural } \\
\text { Sciences, Vertebrate Biology } \\
\text { Clément, Gaël; Muséum national d'Histoire naturelle, Département } \\
\text { Histoire de la Terre - UMR 5143 du CNRS; }\end{array}$ \\
\hline Key Words: & \begin{aligned} tristichopterid, Strud, Famennian, Langlieria, Eusthenodon, Belgium \\
\hline\end{aligned} \\
\hline
\end{tabular}

\section{SCHOLARONE Manuscripts}


Tristichopterids (Sarcopterygii, Tetrapodomorpha) from the Late Devonian tetrapod-bearing locality of Strud (Belgium, late Famennian), with phylogenetic and paleobiogeographic considerations

\section{SEBASTIEN OLIVE, ${ }^{1,2, *}$ YANN LEROY, ${ }^{1,3,4}$ EDWARD B. DAESCHLER,${ }^{2}$ JASON P.} DOWNS, ${ }^{2,5}$ and GAËL CLEMENT, ${ }^{3}$

${ }^{1}$ OD Earth and History of Life, Royal Belgian Institute of Natural Sciences, Rue Vautier 29, 1000 Brussels, Belgium, sebastien.olive@sciencesnaturelles.be;

${ }^{2}$ Academy of Natural Sciences of Drexel University, 1900 Benjamin Franklin Parkway, Philadelphia, Pennsylvania 19103, USA, ebd29@drexel.edu;

${ }^{3}$ Centre de Recherche en Paléontologie - Paris, UMR CR2P 7207, MNHN/CNRS/SU, CP 38, 57 rue Cuvier, 75231 Paris Cedex 05, France, yann.leroy35@gmail.com, gael.clement@mnhn.fr;

${ }^{4}$ Laboratoire de Paléontologie, Géosciences, CNRS UMR 6118, Université de Rennes 1, 263, avenue du Général Leclerc, 35042 Rennes cedex, France;

${ }^{5}$ Department of Biology, Delaware Valley University, 700 East Butler Avenue, Doylestown, Pennsylvania 18901, U.S.A., jason.downs@delval.edu.

* Corresponding author

RH: OLIVE ET AL.-TRISTICHOPTERIDS FROM BELGIUM 


\begin{abstract}
We describe new material of the tristichopterids cf. Langlieria socqueti and cf. Eusthenodon wangsjoi and other unassignable tetrapodomorph remains from the late Famennian locality of Strud, Belgium. Because of recent improvements in our tristichopterid knowledge, a new phylogenetic analysis is presented in addition to a paleobiogeographic analysis using the Bayesian Binary MCMC statistical method. A clade formed by (Langlieria socqueti ((Edenopteron keithcrooki + Hyneria lindae) (Heddleichthys dalgleisiensis (Cabonnichthys burnsi (Mandageria fairfaxi + Eusthenodon wangsjoi))))) represents the most highly-nested tristichopterids and the biogeographic analysis supports a Western European origin for it. The biogeographic analysis additionally proposes several tristichopterid dispersal events between Euramerica and Gondwana from the Givetian to Famennian, providing a more complex scenario than the one proposed by the Great Devonian Interchange.
\end{abstract}

\title{
INTRODUCTION
}

Tristichopteridae is a clade of elongate, aquatic sarcopterygians with an extratemporal bone located between opercular and lateral extrascapular bones (Ahlberg and Johanson, 1997; Johanson and Ahlberg, 1997; Snitting, 2008a). Scales are devoid of cosmine, rounded and thin with a small median boss on the internal surface. The caudal fin is trifurcate and diamond-shaped in derived forms (Cloutier and Ahlberg, 1996).

Tristichopterids are known from the Middle Devonian (latest Givetian; Egerton, 1861; Young et al., 1992; Swartz, 2012) through the Upper Devonian (Famennian; Jarvik, 1952; Clément, 2002; Clément et al., 2009). Their body sizes ranged from 30 centimeters to several meters in length. These lobe-finned predatory vertebrates are quite common in the Devonian vertebrate assemblages of the world with about twenty described species, but only 
Eusthenodon wangsjoi has a cosmopolitan distribution (Laurussia and Gondwana; Ahlberg et al., 2001; Clément, 2002; Clément and Boisvert, 2006; Clément et al., 2009). Unassignable tristichopterid remains are known from Morocco (Lehman, 1977; Lelièvre and Janvier, 1986; Lelièvre et al., 1993), from Colombia (Janvier and Maisey, 2010; Olive et al., in review) and probably from Iran (Davesne et al., 2015).

Several studies have been done on tristichopterids from Belgium (Lohest, 1888;

Cloutier and Candilier, 1995; Clément, 2002; Clément et al., 2009; Olive et al., 2015a). Eusthenodon wangsjoi and Langlieria socqueti were described from Durnal, Namur Province (Clément, 2002; Clément et al., 2009); cf. Langlieria from Dison and Modave, Liège Province (Clément et al., 2009); and unassignable tristichopterid scales from Becco, Liège Province (Olive et al., 2015a). Tristichopterid remains have also been reported from the locality of Strud, Namur Province (Clément et al., 2009; Denayer et al., 2016:table 1); and Evieux, Liège Province (Clément et al., 2009).

We report here on new tristichopterid material from the tetrapod-bearing locality of Strud. We also provide a new phylogenetic analysis that was prompted by recent improvements in our knowledge of tristichopterid diversity (Swartz, 2012; Schultze and Reed, 2012; Young et al., 2013; Borgen and Nakrem, 2016; Daeschler and Downs, 2018; Downs et al., 2018). We use our resulting cladogram as the basis for a study of the paleobiogeographic history of Tristichopteridae.

\section{GEOLOGICAL SETTING}

During the late Famennian, Belgium was located along the southeastern margin of Euramerica (London-Brabant Peninsula; Ziegler, 1990). In Wallonia (southern Belgium), Devonian outcrops are present in the Dinant Synclinorium (allochtonous), Vesdre Area, 
Theux Tectonic Window, Brabant Parautochton, and Haine-Sambre-Meuse Overturned Thrust Sheets (HSM OTS; Fig. 1). These Variscan structures form the Namur-Dinant Basin, which developed during Devonian and Carboniferous times (Thorez et al., 2006). Famennian outcrops from Belgium show a regressive trend from shales formed in an open marine environment (Famenne Group, early Famennian) to fluvio-lagunal siltstones, sandstones, and dolomites (Evieux Formation, lower Famennian) (Thorez and Dreesen, 1986). Late Famennian deposits from HSM OTS, Vesdre Area, and Theux Tectonic Window are more proximal and the fluvio-lagunal facies are generally better developed than in contemporary deposits from the Dinant Synclinorium (Thorez et al., 2006). The strata at Strud belong to the HSM OTS. Tristichopterid remains were found in beds A, B, D-D', and E of lithological unit 7 (Fig. 1). Lithological unit 7 belongs to the late Famennian Evieux Formation. The sedimentology of this unit corresponds to the filling sequence of a channel in an alluvial plain (Denayer et al., 2016).

\section{MATERIAL AND METHODS}

\section{Preparation and Imaging}

All specimens were mechanically prepared except for a few specimens that were virtually prepared by conventional X-ray tomography at the AST-RX (Accès Scientifique à la Tomographie à Rayons X) facility of the MNHN. Scanning parameters were as follows: voltage $=85 \mathrm{kV}$, current $=260 \mu \mathrm{A}$; for IRSNB P 9918, number of slices $=3000$, voxel size $=$ $0.029 \mathrm{~mm}$. IRSNB P 9919 is included in three rock blocks that were scanned independently. IRSNB P 9919a, number of slices $=1500$, voxel size $=0.098$ mm; IRSNB P 9919b, number of slices $=2000$, voxel size $=0.098 \mathrm{~mm}$; IRSNB P 9919c, number of slices $=1800$, voxel size $=0.116 \mathrm{~mm}$. IRSNB P 9918 and 9919 were virtually reconstructed with MIMICS 
(Materialise's Interactive Medical Image Control System) 16.0 Software (Materialise Inc.; proprietary software at the MNHN) at the Atelier 3D, Centre de Recherche en Paléontologie Paris, MNHN.

\section{Phylogenetic Analysis}

Ahlberg and Johanson (1997) generated a phylogenetic analysis of Tristichopteridae that has served as a starting point for subsequent analyses focusing on the clade (e.g. Johanson and Ahlberg, 2001; Snitting, 2008b; Clément et al., 2009; Swartz, 2012). The phylogenetic study developed for the present paper considers 15 species and is the first published analysis to include Hyneria lindae and Edenopteron keithcrooki. We chose to perform a species-level analysis because we did not want to assume that the genera are monophyletic. The analysis used 28 morphological characters (SI 1-2). Twenty-three characters come directly or are modified from previous analyses, and five new characters (23-28) are introduced here. In an effort to minimize qualitative assessments in character scoring, we included only characters with well-defined states. We checked character scores against published descriptions and figures, as well as original material for Hyneria lindae and Langlieria socqueti.

We used PAUP 4.0a162 (Swofford, 2002) and the branch-and-bound search algorithm to analyze the complete matrix (SI 2). All characters were ordered, except for character \#26 (maximum height of maxilla in external view). We chose Gogonasus andrewsae and Spodichthys buetleri for the outgroups because they are well known and phylogenetically close to tristichopterids (Long, 1985a; Long et al., 2006; Snitting, 2008b; Holland and Long, 2009). All characters were assigned equal weight and only characters 10, 26, and 28 were defined as multistate. Bremer indices and the minimal and maximal number of synapomorphies have been produced by PAUP at each node to test the node robustness. 
Details of the phylogenetic analysis, and notably the character state changings, are available in SI 3. Only a few character state changings have been reported on the tree in order not to overload the figure.

\title{
Biogeographic Analysis
}

A biogeographic analysis was performed using Bayesian Binary MCMC (BBM), in RASP 3.1 software (Yu et al., 2015). This is a statistical method that uses Bayesian inference to reconstruct the ancestral state or biogeographical origin of clades (Ronquist and Huelsenbeck, 2003). We applied BBM on the consensus tree resulting from the phylogenetic analysis. Nine geographical areas were designated (Australia, Greenland, Canada, Pennsylvania, Nevada, Western Europe, Eastern Europe/Russia, South Africa and Antarctica) and each taxon was assigned to the geographical area(s) where it was found (SI 4). The geographic categories were made according to the Late Devonian paleogeography proposed by Scotese (2014) and Ziegler (1990). For instance, Scotland, England, Belgium were all parts of the Rhenish Basin during the Late Devonian (Ziegler, 1990) and thus were grouped together as "Western Europe". The BBM analysis was performed over $10^{6}$ generations with 10 Markov chains, sampling every 100 generations, with the temperature set to 0.1 . The first one hundred trees were discarded as part of the burn-in period, and the Jukes-Cantor model was used, with equal among-site rate variation. The results of the biogeographic reconstructions for each node are presented in SI 5. The results of the analysis are expressed as the probability of a given clade originating from each of nine continental areas.

\author{
Abbreviations \\ Institutional Abbreviations-IRSNB, Institut royal des Sciences naturelles de \\ Belgique, Brussels, Belgium; MNHN, Muséum national d'Histoire naturelle, Paris, France.
}


Anatomical Abbreviations — a.ad, anterior wall of adductor fossa; ar.hyo, articulation area with hyomandibular; ar.pal, area for palatoquadrate dorsal process (paratemporal process); aut.p, autopalatine process; bu, bulge; cl.d, cleithrum postero-dorsal crest; cl.m, cleithrum mesial crest; co.1, anterior coronoid; co.2, middle coronoid; co.3, posterior coronoid; d, dentary; d.d, dentary marginal dentition; d.f, dentary fang; d.s, dentary suture; ent.pa, anterior process of entopterygoid; f.co.1, anterior coronoid fang; f.co.2, middle coronoid fang; f.co.3, posterior coronoid fang; f1.co.3, anterior fang of posterior coronoid; f2.co.3, second fang of posterior coronoid; f3.co.3, posterior fang of posterior coronoid; fo.ico, intercoronoid fossa; fo.pco, precoronoid fossa; inf.1-4, infradentaries; l.d, dorsal lamina of cleithrum; l.pb, dorsal blade post-branchial lamina of cleithrum; l.v, ventral lamina of cleithrum; la.l, lateral vertical lamina; la.m, mesial vertical lamina; m.ad, posterior part forming the mesial part of the adductor fossa; md.g, mandibular sensory groove; $\mathbf{0 . r}$, oblique ridge; ov.ano, area of cleithrum overlapping anocleithrum; ov.br, branchial operculum overlapping area; ov.cla, clavicle overlapping area; ov.it, intertemporal overlapping area; ov.j, jugal overlapping area; ov.l.ext, lateral extrascapular overlapping area; ov.mx, maxilla overlapping area; ov.p.sr, posterior supraorbital overlapping area; ov.po, postorbital overlapping area; ov.pop, preopercular overlapping area; ov.psp, postspiracular overlapping area; ov.qj, quadratojugal overlapping area; ov.sm1, submandibular 1 overlapping area; ov.sq, squamosal overlapping area; ov.st, supratemporal overlapping area; ov.ta, tabular overlapping area; p.g, parietal sensory groove; pi, pineal area; pr.a, anterior process; pr.ad, antero-dorsal process; pop.g, preopercular sensory groove; ppr, posterior process of postorbital; r.f, replacement pit of middle coronoid fang; ri.it.so, ridge dividing intertemporal and postorbital overlapping areas; ri.ioc, ridge housing infraorbital sensory canal; sp.n, spiracular notch. 


\title{
SYSTEMATIC PALEONTOLOGY
}

\author{
SARCOPTERYGII Romer, 1955 \\ OSTEOLEPIFORMES Berg, 1937 \\ TRISTICHOPTERIDAE Cope, 1887 \\ cf. LANGLIERIA Clément, Snitting and Ahlberg, 2009
}

Type Species-Langlieria socqueti Clément, Snitting and Ahlberg, 2009.

cf. LANGLIERIA SOCQUETI Clément, Snitting and Ahlberg, 2009

(Fig. 2)

\begin{abstract}
Referred Material—IRSNB P 9912, partial left squamosal (bone has been mechanically removed to have access to the mould of the external surface), and IRSNB P 9913, right mandible.
\end{abstract}

Locality and Horizon — Strud quarry, Namur Province, Belgium, Evieux Formation, late Famennian, Late Devonian.

Remarks - Two tristichopterid species have been described from Belgium: Eusthenodon wangsjoi and Langlieria socqueti. We assign the following material (isolated squamosal and lower jaw) to cf. Langlieria socqueti according to dermal ornament and size category. Of the two specimens described here, only one (IRSNB P 9913) exhibits a feature included in the diagnostic character combination of Clément et al. (2009) and this feature (presence of dentary fang pair) is present in most tristichopterids. The one autapomorphy that Clément et al. (2009) cite for L. socqueti (absence of marginal vomerine teeth; Clément et al., 2009) is impossible to address in the new material. 


\section{Description}

Squamosal-The squamosal (IRSNB P 9912; Fig. 2A-C) exhibits a prominent rostrodorsal process and a less prominent rostromedial process. The dorsal margin of the bone is concave and the dorsocaudal corner is rounded and located well rostral to the caudoventral portion of the squamosal. The dermal surface of the squamosal contains wide, conjoined areas for the overlap of the postorbital and jugal bones. There is a narrow area for the overlapping maxilla along the ventral margin. The relationship between squamosal and maxilla is reversed in IRSNB P 9912 relative to the condition in a partial skull of L. socqueti (MNHN ARD 250) from the type locality (squamosal overlaps maxilla; Clément, 2002:textfigs. 8-9). Maxilla overlap onto the squamosal is the more common condition in Tristichopteridae; the reversed condition is otherwise known only in Eusthenodon wangsjoi and possibly Platycephalichthys bischoffi (Clément, 2002). On the visceral surface of IRSNB P 9912, along the dorsal margin, there is an elongated and narrow area of overlap onto supratemporal, tabular, and possibly postspiracular.

Lower Jaw - The dentary displays a large fang pair with cutting edges and ridges on its base. Ridges are absent or not preserved on the apex. As in MNHN ARD 251 (Clément et al. 2009:text-fig. 7), there is no marginal dentition of the dentary labial to the fangs or between the fangs and the mandibular symphysis (IRSNB P 9913, Fig. 2D-F). Among tristichopterids, a marginal dentary tooth row that appears only distal to the fangs is additionally observed in Cabonnichthys burnsi (Johanson and Ahlberg, 1997), Edenopteron keithcrooki (Young et al., 2013), and Eusthenodon wangsjoi (Jarvik, 1952; Johanson, 2004).

The distal end of infradentary 4 in IRSNB P 9913 shows a wide and ventrally slanting area of overlap for the quadratojugal. Ventral to the quadratojugal overlap area is a long 
eroded mandibular groove. The overlapping area for the first submandibular can be observed on the ventral part of infradentary 1 (IRSNB P 9913, Fig. 2D-E).

Only one fang of coronoid 3 is visible in IRSNB P 9913 (Fig. 2D-F). The number of fang pairs on coronoid 3 is impossible to determine in this specimen and the condition is unknown in L. socqueti. Among tristichopterids, only Spodichthys buetleri (Snitting, 2008b), Tristichopterus alatus (Snitting, 2009), and E. keithcrooki (Young et al., 2013) are reported with one fang pair, rather than two, on coronoid 3. The coronoid fangs of IRSNB P 9913 exhibit cutting-edges and striations at the base that may or may not reach to the apex of the tooth.

Dermatocranial Ornament-The dermatocranial ornament of IRSNB P 9912 and IRSNB P 9913 is very fine. IRSNB P 9912 (squamosal) exhibits subparallel ridges in the rostrodorsal part of the bone and anastomosing ridges elsewhere. On IRSNB P 9913 (dentary + infradentaries), the ornament is mainly made of smooth anastomosed ridges, which are more strongly pronounced at the distal end of the dentary.

cf. EUSTHENODON Jarvik, 1952

Type Species_Eusthenodon wangsjoi Jarvik, 1952. cf. EUSTHENODON WANGSJOI Jarvik, 1952

(Figs 3-4, SI 6-7)

Referred Material-IRSNB P 9910, partial left parietal; IRSNB P 9914, left supratemporal, part and counterpart; IRSNB P 9915, partial left postorbital; IRSNB P 9916, 
left preopercular; IRSNB P 9917, left opercular; IRSNB P 9918, right dentary; IRSNB P 9919, partial right mandible.

Locality and Horizon - Strud quarry, Namur Province, Belgium, Evieux Formation, late Famennian, Late Devonian.

Remarks - These specimens are referred to cf. Eusthenodon wangsjoi on account of dermal ornament and size category. In addition, IRSNB P 9915 (postorbital) shares general shape characteristics with the E. wangsjoi holotype (P. 1476) in addition to a well-developed rostrodorsal process (Jarvik, 1952:pl. 9). IRSNB P 9917 (preopercular) has a wide rostroventral process similar to that observed in the E. wangsjoi holotype (Jarvik, 1952:pl. 10). General shape characteristics are shared between IRSNB P 9914 (supratemporal) and IRSNB P 9918 (opercular) and the E. wangsjoi holotype (Jarvik, 1952:pl. 9). IRSNB P 9919 (mandible) shares with the E. wangsjoi holotype (Jarvik, 1952:pl. 10) a lack of fusion among the dermatocranial mandibular bones.

\section{Description}

Parietal-IRSNB P 9910 (Fig. 3A-B) is an isolated partial parietal that preserves much of the caudal margin and the medial margin. The dermal surface of the parietal exhibits a short area of supratemporal overlap along the caudolateral margin. The posterior oblique pitline groove is observed lateral to the pineal region. The shape of the parietal suggests a kite-shaped pineal series, contrary to the tear-drop shaped condition in the Eusthenodon wangsjoi holotype (P. 1476; Jarvik, 1952:pl. 9) and in Clément's (2002) emended diagnosis of the species. In addition, it appears as though the pineal series either reaches or nearly reaches the caudal margin of the parietal shield. Several specimens of E. wangsjoi (including the holotype, P. 1476; Jarvik, 1952:pl. 9) show a more rostrally positioned pineal series. High 
variability of pineal positioning in E. wangsjoi has previously been recognized by Jarvik (1985).

Supratemporal-IRSNB P 9914 (Fig. 3C-F) is widest along its caudal margin and the spiracular notch is strongly hook-shaped. This shape is quite different from what is observed in the Eusthenodon wangsjoi holotype (P. 1476; Jarvik, 1952) and more closely resembles the condition observed in Eusthenopteron foordi (e.g., Jarvik, 1944a). Areas overlapped by the intertemporal and postorbital are observed on the dermal surface of the supratemporal (Fig. 3C), in the rostrolateral corner. A strong ridge divides the two overlap areas (Fig. 3E) as in Langlieria socqueti (Clément, 2002:text-fig. 6B). On the visceral surface, a smooth depression is visible anteriorly. This depression may have received the palatoquadrate paratemporal process (as proposed by Clément, 2002, for E. wangsjoi). The ridge housing the infraorbital canal is present around this depression. A possible articulation area with the hyomandibula is located in the caudomedial corner (Fig. 3F).

Postorbital-IRSNB P 9915 (Fig. 3G-H) is an isolated partial postorbital with an extended shared area for the overlap of both intertemporal and posterior supraorbital bones. These overlap areas are not observable in the Eusthenodon wangsjoi type material.

Preopercular-IRSNB P 9916 (Fig. 3I-J) is a partial left preopercular that preserves an area for squamosal overlap that appears short but may be incomplete.

Opercular-IRSNB P 9917 (Fig. 3K-L) is an opercular with a high height/length ratio (1.5). Jarvik (1952) described the opercular of Eusthenodon wangsjoi as higher than long and figures a single specimen (P. 1481, Jarvik, 1952:pl. 12:2) with a ratio that is not as high (=1.24) as that in IRSNB P 9917. The ventral margin of IRSNB P 9917 is rounded as in Eusthenopteron foordi (e.g., Jarvik, 1944a) and is notably unlike the condition in Cabonnichthys burnsi (Ahlberg and Johanson, 1997:fig. 3), where the margin is indented by the subopercular. The dorsal margin of IRSNB P 9917 shows a well-developed and large 
overlap area divided in two parts by a ridge. The larger rostral part was probably for the postspiracular bone and the smaller caudal part for the lateral extrascapular. In E. wangsjoi, only the overlap area for the postspiracular has been previously reported (by Jarvik, 1952:pl. 12:2). However, Jarvik (1952:64) expresses doubt over whether the area was overlapped by the postspiracular or the lateral extrascapular. The rostral margin of IRSNB P 9917 displays a very narrow overlap area for the preopercular.

Lower Jaw-IRSNB P 9918 (Fig. 4A-B) exhibits a dentary fang pair and no marginal teeth are observed from the fang pair to the symphysis. Within Tristichopteridae, this condition is shared among Cabonnichthys burnsi (Johanson and Ahlberg, 1997), Edenopteron keithcrooki (Young et al., 2013), and Eusthenodon wangsjoi (Jarvik, 1952; Johanson, 2004). IRSNB P 9919 (Fig. 4D-F) includes all three coronoids. Coronoid 3 is much longer than coronoids 1 or 2. Among tristichopterids, only Spodichthys buetleri (Snitting, 2009) and Tristichopterus alatus (Snitting, 2009) have been reported with a third coronoid of a length subequal to coronoids 1 and 2 . The fangs of coronoids 1 and 2 have sharp carinae along mesial and distal margins. The fangs of both pairs on coronoid 3 are much smaller than those of coronoids 1 or 2 . No striations are visible on the coronoid fangs of IRSNB P 9919. A marginal tooth row is not visible on any of the three coronoids of IRSNB P 9919. This may be a result of preservation; no other tristichopterid is without marginal coronoid dentition. Among tristichopterids, the most reduced condition previously recognized (marginal teeth on third coronoid only) is observed in E. wangsjoi (Jarvik, 1952), Hyneria lindae (Daeschler and Downs, 2018), and M. fairfaxi (Johanson and Ahlberg, 1997).

Dermatocranial Ornament-As described in Clément's (2002) emended diagnosis for Eusthenodon wansgjoi, the dermatocranial ornament of these Strud specimens consists of ridges forming distinct networks and independent tubercles are rare. 


\section{DESCRIPTION OF OTHER TRISTICHOPTERID MATERIAL FROM STRUD}

Unless otherwise noted, the specimens reported below are referred to cf. Tristichopteridae sp. indet. according to shapes, sizes, and dermal ornaments that compare more favourably to Strud's tristichopterids than to the other vertebrates at the locality (acanthodians, actinopterygians, antiarchs, arthrodires, phyllolepids, porolepiforms, rhizodonts, osteolepidids, dipnoans, tetrapods; Lohest, 1888; Leriche, 1931; Clément et al., 2004; Clément and Boisvert; 2006; Olive, 2015; Olive et al., 2015b, 2016a, 2016b). Absence of diagnostic features prevents more specific taxonomic assignments. Taxonomic caution is especially warranted in the cases of isolated tetrapodomoprh cleithra and suboperculars. Several authors have reported on the intraspecific variability of cleithrum morphology and ornament and of subopercular morphology in tetrapodomorphs (Andrews and Westoll, 1970; Jarvik, 1944b). For many of the specimens presented here, very little meaningful anatomical description is possible. Our intention then is to simply present an inventory of potential tristichopterid material produced by recent collecting efforts at the Strud locality.

IRSNB P 9920 (Fig. 5A) is a right preopercular with a deep dorsal-ventral sensory groove in its caudal half. Its ornamentation comprises small tubercles and ridges.

IRSNB P 9921-9923 (Fig. 5B-D) are isolated subopercular bones. The rostral process of IRSNB P 9921 is especially long and rod-like (Fig. 5B). IRSNB P 9923 is much smaller than the other two and has a more rounded shape with a short, stout rostral process (Fig. 5D).

IRSNB P 9911 (Fig. 5E-F) is a partial right entopterygoid and palatoquadrate. Much of the preserved entopterygoid is without denticles although this is possibly due to weathering. A large and rounded oblique ridge is present in the middle of the bone. This ridge runs caudodorsally and broadens from a prominent rounded bulge (Fig. 5F). The rostral end of the specimen exhibits a pronounced autopalatine process and a ventral process of the 
entopterygoid with a short triangular groove between them that tapers caudally. A prominent ascending process is partially observed at the dorsal preservational limit. A row of large and pointed denticles appear along the ventral margin of the entopterygoid's rostral end. The ventral margin of the palatoquadrate is relatively straight and does not exhibit the wide lateral flange that surrounds the caudal end of the ectopterygoid in Eusthenodon wangsjoi (Jarvik, 1952:pl. 16:2).

IRSNB P 9924-9927 are isolated cleithra. The dorsal lamina ornament of IRSNB P 9924 (Fig. 6A-B) is a network of generally parallel fine anastomosed crests; that of IRSNB P 9926 and IRSNB P 9927 (Fig. 6E-F) is coarse tubercles and small ridges similar to cleithrum ornament of Platycephalichthys bischoffi (Vorobyeva, 1959, 1962) and Langlieria socqueti (Clément, 2002; Clément et al., 2009). The dorsal lamina of IRSNB P 9925 (Fig. 6D) is generally smooth, perhaps due to weathering. In IRSNB P 9925, a long crest follows the caudal margin of the dorsal lamina's visceral surface. (Fig. 6D).

IRSNB P 9928 and 9929 (Fig. 6G-H) are isolated fangs with ridges along their base and sharp carinae along mesial and distal edges.

IRSNB P 9930-9933 (Fig. 6I-L) are isolated scales. Each shows the visceral boss that allows an assignment to Tristichopteridae sp. indet. Several (IRSNB P 9930-9931, IRSNB P 9933) show radiating grooves on the free margin.

\section{RESULTS}

\section{Phylogenetic Analysis}

The phylogenetic analysis of the complete data matrix yielded three most parsimonious trees with a score of $62(\mathrm{CI}=0.5 ; \mathrm{RI}=0.617 ; \mathrm{RCI}=0.309)$. Figure 7 presents the $50 \%$ majority-rule consensus tree that was generated from the data. Bremer indices are all 
equal to 1 except the clade (Cabonnichthys burnsi (Mandageria fairfaxi + Eusthenodon wangsjoi)), which has a Bremer index of 2.

Usually considered as a tristichopterid, Tristichopterus alatus has an unresolved basal position in our phylogenetic analysis. It belongs to the basal polytomy with the two outgroups and the rest of the tristichopterids (node 11).

Node 11 is characterized by five synapomorphies: presence of epichordal radials in the caudal fin (character 1, state 1), a pineal foramen well posterior to orbits $(9,1)$, two fang positions on posterior coronoid $(12,1)$, a posterior coronoid much longer than middle coronoid $(13,1)$ and a dentary fang pair $(18,1)$.

Node 10 is characterized by a symmetrical caudal fin $(2,1)$, a posterior process of the posterior supraorbital much longer than its orbital margin $(7,1)$, two fang positions on ectopterygoid $(11,1)$, less than half of the lacrimal rostral to orbit $(27,1)$ and the presence of an extratemporal in a postspiracular position $(21,1)$.

Eusthenopteron (node 1) is characterized by the lack of epichordal radials in the caudal fin $(1,0)$, the absence of a dentary fang pair $(18,0)$ and a straight or slightly concave lateral margin of the vomer's caudal process $(19,1)$.

In our analysis, and contrary to Borgen and Nakrem (2016), the ancestral character state for the premaxillary dentition (character 10) is not homodonty (morphotype A, state 0 ), but instead a gradual tooth size increase with proximity to the symphysis (state 1). Homodonty is a derived character, which occurred independently in Spodichthys buetleri, Eusthenopteron wenjukowi, and Platycephalichthys bischoffi. A single, greatly enlarged premaxillary fang (state 2; morphotypes $\mathrm{C}$ and $\mathrm{D}$ of Borgen and Nakrem, 2016) supports the clade of Famennian tristichopterids (node 7). It also appears independently in Tinirau clackae. The Famennian tristichopterid clade (node 7) is also supported by the lack of dentary marginal teeth near the symphysis $(14,1)$. 
In this analysis, the best supported clades are (Hyneria lindae + Edenopteron keithcrooki) (minimal and maximal number of synapomorphies of five and six) and ((Eusthenodon wangsjoi + Mandageria fairfaxi) Cabonnichthys burnsi) (Bremer index of 2). The first is characterized by the absence of contact between the posterior supraorbital and the intertemporal (5.1), an apical fossa divided in two $(20,1)$, a flat to concave denticulated field of the parasphenoid $(22,0)$, a 0.5 or greater width/length ratio of vomers + parasphenoid $(23,0)$, a 0.5 or greater width/length ratio of parietals $(24,1)$, and a maxilla overlap onto squamosal (25,0). Edenopteron keithcrooki has only one fang position on its posterior coronoids $(12,0)$ and this reversal makes it unique within the Famennian tristichopterid clade (node 7).

The second of the best supported clades, ((Eusthenodon wangsjoi + Mandageria fairfaxi) Cabonnichthys burnsi), is characterized by the absence of a vertical blade-like lamina lateral to the fangs of coronoid $1(15,1)$, a marginal coronoid tooth row on coronoid 3 only $(28,2)$, the presence of accessory vomers $(16,1)$ and a maxilla of equal height along its entire length (26,2). E. wangsjoi and M. fairfaxi share the following combination of characters: jugal excluded from orbital margin $(3,1)$, an absence of contact between posterior supraorbital and intertemporal $(5,1)$, a contact between posterior supraorbital and lacrimal $(6,1)$, absence of a marginal tooth row mesial to the dermatopalatine fang $(17,1)$ and half or more of the lacrimal appears rostral to the orbit $(27,0)$. The relationships among E. wangsjoi, M. fairfaxi and C. burnsi agree with the results of Ahlberg and Johanson (1997, 1998, 2001) and place Cabonnichthys as the sister taxon of (Eusthenodon + Mandageria).

\section{Biogeographic Analysis}

Clade 7 includes the most derived tristichopterids: Langlieria socqueti, Edenopteron keithcrooki, Hyneria lindae, Heddleichthys dalgleisiensis, Cabonnichthys burnsi, 
Mandageria fairfaxi and Eusthenodon wangsjoi. This node is reconstructed with a Western Europe origin ( $\sim 84 \%$ probability).

Clade 4 gathers taxa (Cabonnichthys burnsi, Mandageria fairfaxi and Eusthenodon wangsjoi) with an Australian origin ( $\sim 81 \%$ probability) and clade 2 groups taxa (Edenopteron keithcrooki and Hyneria lindae) with a possible Australian origin ( $67 \%)$.

The major conflict in the biogeographic reconstruction occurs at the root node 12 where the Australian origin is supported at $30 \%$, the Greenland origin at $28 \%$, the Western Europe origin at $22 \%$ and the Nevada origin at $7 \%$. This is explained by the basal polytomy and the choice of the outgroups, which are themselves of Australian (Gogonasus andrewsae) and Greenland (Spodichthys buetleri) origins.

The basal position of Tinirau clackae and Notorhizodon mackelveyi suggest a Western North America (Nevada) origin for the clade 11 ( $\sim 62 \%$ probability) and an Antarctic origin for clade 10 ( $\sim 63 \%$ probability).

\section{DISCUSSION}

\section{Phylogenetic Analysis}

As mentioned by Schultze and Reed (2012), interrelationships of tristichopterids have been very stable over the years and have changed only by addition of new taxa. This is the case in the present analysis. Most recent phylogenetic analyses of tristichopterids support a highly nested clade of tristichopterids including variably Cabonnichthys, Eusthenodon, Mandageria, (Ahlberg and Johanson, 1997, 1998; Johanson and Ahlberg, 2001; Zhu and Ahlberg, 2004; Snitting, 2008b; Clément et al., 2009; Swartz, 2012) and Langlieria (Clément et al., 2009). The present analysis gathers the same taxa (node 7) and additionally includes Hyneria lindae and Edenopteron keithcrooki, both included for the first time in a published 
phylogenetic analysis. The clade of Famennian tristichopterids that originates at node 7 additionally includes Heddleichthys dalgleisiensis.

Position of Spodichthys — Spodichthys is basal to all tristichopterids in all phylogenetic analyses where it is included (Snitting, 2008a, 2008b; Clément et al., 2009). It displays a number of plesiomorphic characters such as the absence of contact between the posterior supraorbital and the intertemporal $(5,1)$, the pineal foramen located at the level with or anterior to the posterior margin of the orbit $(9,0)$, only one fang position on the ectopterygoid and third coronoid (11,0 and 12,0), a third coronoid similar in length to the middle coronoid $(13,0)$, the presence of a vertical lamina lateral to the coronoid fang on the anterior coronoid $(15,0)$, the absence of a dentary fang pair $(18,0)$ and a width/length ratio of vomers + parasphenoid equal to or more than $0.5(23,0)$. In our analysis, Spodichthys buetleri appears in a basal polytomy together with Gogonasus andrewsae, Tristichopterus alatus and a clade that contains all other Tristichopteridae. The phylogenetic position of S. buetleri remains an open question because more than half of the characters are missing data (19 of 28). It is considered to be the sister group of Tristichopteridae by Snitting (2008b) because it cannot be demonstrated that its extratemporal reaches into the postspiracular area, a feature that diagnoses Tristichopteridae.

Monophyly of Tristichopteridae - Tristichopterid monophyly has been established in several studies (Long, 1985b; Ahlberg and Johanson, 1997, 1998; Johanson and Ahlberg, 2001; Zhu and Ahlberg, 2004; Snitting, 2008a, 2008b; Clément et al., 2009). In the present analysis, because of the low resolution at the base of the tree, this monophyly is not specifically supported. The presence of an extratemporal in a postspiracular position $(21,1)$, a feature used to diagnose members of Tristichopteridae, is here regarded as a synapomorphy of clade 10 only. It is absent in Tinirau clackae (the 'postspiracular' is in a rostral position) and its presence in Tristichopterus alatus is regarded as a convergence. 
Newly Added Taxa-Edenopteron keithcrooki and Hyneria lindae are included in a phylogenetic analysis for the first time and these appear as sister species to one another (node 2). Node 2 is supported by six synapomorphies (see Results) including the division of the apical fossa into two parts, a condition that is unique within Tristichopteridae.

The position of $H$. lindae within tristichopterids appears as less derived than previously thought by several authors (Daeschler and Shubin, 2007; Clément et al., 2009; Daeschler and Downs, 2018). In a previous publication by two of us (Daeschler and Downs, 2018), a highly nested phylogenetic position for $H$. lindae was proposed due to a suite of characters that includes contact between parietal and postorbital, a postorbital that does not contribute to the orbital margin, a wide and concave denticulated plate of the parasphenoid, a dentary fang pair, and a lack of marginal dentition on all but the third coronoid. Except for the last character $(28,2)$, the new phylogenetic analysis supports all of these as either derived features appearing quite early in the history of tristichopterids (dentary fang pair $(18,1)$ and lack of postorbital contribution to orbital margin $(4,1)$ ) or plesiomorphic for the group (wide and concave denticulated plate of the parasphenoid, 22,0).

Edenopteron keithcrooki was also presumed to be phylogenetically highly nested (Young et al., 2013) on account of characters including accessory vomers and contact between parietal and postorbital. According to our analysis, while the presence of accessory vomers suggests a derived tristichopterid, the rest of the character states support its sister group relationship with $H$. lindae.

Tinirau clackae was previously included in the phylogenetic analysis of Swartz (2012) but this analysis used a large dataset including Devonian and Carboniferous tetrapodomorphs. As noticed by Young et al. (2013), the character list diluted characters relevant to tristichopterids and pushed T. clackae and Platycephalichthys out of Tristichopteridae. In Swartz's (2012) cladogram, Platycephalichthys was sister group to 
Elpistostegalia and Tinirau was sister group to (Platycephalichthys + Elpistostegalia). In our analysis, the only species in these two groups occupy basal position within Tristichopteridae.

Mandageriidae - The subfamily Mandageriidae was established by Young (2008) and includes Gondwana tristichopterid taxa: Mandageria fairfaxi, Cabonnichthys burnsi, possibly Notorhizodon mackelveyi and Edenopteron keithcrooki (referred to as the "undescribed tristichopterid from near Eden, NSW" in Young, 2008). According to Young (2008), who did not perform a phylogenetic analysis to support his assertion, features justifying the erection of this subfamily were a shared scale morphology and the presence of accessory vomers. This pairing is counter to the relationships presented in Ahlberg and Johanson's (1997) phylogenetic analysis, wherein M. fairfaxi is the sister group of Eusthenodon wangsjoi, not Cabonnichthys burnsi. One of Young's (2008) arguments against the pairing of M. fairfaxi and E. wangsjoi was the weakness of the only synapomorphy that supported it. According to Young (2008), absence of contact between intertemporal and posterior supraorbital is impossible to assess in M. fairfaxi.

In our phylogenetic analysis, we respond to the issues raised by Young (2008). The "accessory vomers" character has been added (ch.16; as it was already done by Clément et al., 2009). We scored character 5 (contact between posterior supraorbital and intertemporal) in the same way as Ahlberg and Johanson (1997) for Mandageria fairfaxi and Cabonnichthys burnsi since we do not have access to the type material, but whereas the absence of contact was only a shared character by E. wangsjoi and M. fairfaxi, in our matrix, it is additionally shared by E. keithcrooki and H. lindae. We also add characters and key species that should help to address the validity of the subfamily Mandageriidae (i.e., N. mackelveyi and E. keithcrooki).

The relationships supported by our analysis are those originally presented by Ahlberg and Johanson (1997, 1998) and also Clément et al. (2009): (C. burnsi (M. fairfaxi + E. 
wangsjoi)). The clade (M. fairfaxi + E. wangsjoi $)$ is supported by five synapomorphies and displays a minimal and maximal numbers of synapomorphies of four and six. Mandageriidae appears as paraphyletic here and is therefore not considered to be valid.

Newly Added Characters - Compared to previous phylogenetic studies on tristichopterids, six new characters have been added in our analysis, some of them based on observations made on Hyneria lindae. Half of the new characters (23, 24, and 25) represent unexpected synapomorphies for the clade including Hyneria lindae and Edenopteron keithcrooki. Characters 23 and 24 are width/length ratios implying a widening of the palate and of the skull roof, respectively, in clade 17. A marginal coronoid tooth row that is only present on coronoid 3 represents a new synapomorphy for the highly nested group of tristichopterids: (Cabonnichthys burnsi (Mandageria fairfaxi + Eusthenodon wangsjoi)).

\section{Biogeographic History of Tristichopteridae}

There is a perfect congruence between the phylogenetic and stratigraphic data (Fig. 7). The origin of the whole group would be, at least, Givetian in age if we consider the oldest occurrence of tristichopterids, i.e. Tristichopterus alatus, Notorhizodon mackelveyi, and Tinirau clackae (Egerton, 1861; Young et al., 1992; Swartz, 2012; Schultze and Reed, 2012). More derived tristichopterids (Eusthenopteron foordi, Eusthenopteron wenjukowi and Platycephalichthys bischoffi) are Frasnian in age and the most derived clade (from node 7) is Famennian in age.

Concerning the origin of the Tristichopteridae whole group (except Tristichopterus alatus, which is in the basal polytomy), node 11 is unambiguously reconstructed with a Western North American origin. This Laurussian origin agrees with Ahlberg and Johanson (1997) and disagrees with Young (2008) who argued for a Gondwanan origin of the whole group. This Western North American origin is mainly due to the basal position of Tinirau 
clackae, which comes from this area. This is also due to the fact that Tristichopterus alatus ends up in the basal polytomy. If it instead occupied a resolved and most basal position within Tristichopteridae (as in Clément et al., 2009; Ahlberg and Johanson, 1997), the origin of the entire group would be Western European.

The origin of node 10 is reconstructed with a Gondwanan origin (Antarctica). This is explained by the basal position of Notorhizodon mackelveyi. According to these results, and as previously proposed by Johanson and Ahlberg (2001), tristichopterids would have already achieved a worldwide distribution as early as the Givetian. Our biogeographic analysis also proposes dispersal from Gondwana (Antarctica) to Laurussia (Eastern Europe) during the Givetian-Frasnian (node 10 to 9).

During the Late Devonian Period, our results support an expansion of tristichopterids from Eastern Europe into Western Europe (node 8 to node 7). Much of tristichopterid history took place in Laurussia (nodes 1 and 5-9), first in Eastern Europe (nodes 9, 8, and 1) and then in Western Europe (nodes 5-7), with the introgression of one taxon (Eusthenopteron foordi) into Western Laurussia (Canada).

According to these results, while some tristichopterids remained in Europe during the Famennian (Heddleichthys dalgleisiensis and Langlieria socqueti), dispersal events occurred from Western Europe to Australia (one from node 6 to 2 and another from node 5 to 4 ) and at least once from Australia to Eastern North America (H. lindae). Eusthenodon wangsjoi, with its remarkable distribution, expanded out of Australia, in the Famennian, to reach Greenland, Europe, and Antarctica. These hypothesized Famennian tristichopterid dispersal events are difficult to reconcile with modern paleogeographic reconstructions. We might expect such discrepancies to result from our still fragmentary understanding of both tristichopterid diversity and species-scale geographic distributions (most tristichopterid species are only known from a single geographic locality). 
The Gondwana-Euramerica Devonian vertebrate interchange (or Great Devonian Interchange) (e.g., Janvier and Villarroel, 2000; Janvier and Clément, 2005; Young, 2008) is a proposed southward dispersion of reputedly Euramerican endemics (Holoptychius, Strepsodus and Asterolepis) in the Frasnian followed by a northward dispersion of Gondwanan endemics (Groenlandaspis, phyllolepids, rhizodontids and megalichthyids) in the Famennian. This Frasnian-Famennian faunal interchange, at least in the southward direction, has recently been weakened by Olive et al. (in review). The present study supports several interchanges between Euramerica and Gondwana during the Middle-Late Devonian. The first is a southward migration during the Givetian (node 11 to 10) and could correspond to a time-extended southward migration of the Great Devonian Interchange. The second is a Givetian-Frasnian northward migration (node 10 to 9) that contradicts the Interchange, and then there are several Famennian migrations, mainly in the southward direction. Although our results are preliminary, they lend some support to tristichopterid distributional patterns that are more complex than the proposed Great Devonian Interchange.

\section{ACKNOWLEDGMENTS}

We thank A. Impens and S. Berton (IRSNB) for preparation of part of the fossils described herein, and T. Hubin (IRSNB) for photographs. We are grateful to C. Cousin and A. Folie (IRSNB) for curatorial support; to F. Solé (IRSNB) and K. Le Verger (MNHN) for their support with RASP software; and to S. Ladevèze (MNHN) for her support with PAUP software. We also thank D. Snitting (Uppsala University) for sending us a copy of his thesis (Snitting, 2008a). We gratefully acknowledge M. Garcia Sanz at the X-ray Tomography Imagery Platform AST-RX of the UMS2700, MNHN, Paris, France (funded by MNHN, CNRS, Institut de France, Région Ile-de-France) for the X-ray tomography scans. Thanks are 
also due to F. Goussard and D. Germain (UMR 7207 MNHN/CNRS/UPMC) for their help in the 3D modelling process. We thank the Gesves local council staff for providing technical support and excavation permission in Strud. We are indebted to the successive Strud field teams, who helped us since 2004. Finally, we thank the editor and the reviewers who helped to improve the quality of the manuscript. This study was partly funded by the Belgian Federal Science Policy Office (doctoral fellowship to S. Olive). 


\section{LITERATURE CITED}

Ahlberg, P. E., and Z. Johanson. 1997. Second tristichopterid (Sarcopterygii, Osteolepiformes) from the Upper Devonian of Canowindra, New South Wales, Australia, and phylogeny of the Tristichopteridae. Journal of Vertebrate Paleontology $17: 653-673$.

Ahlberg, P. E., and Z. Johanson. 1998. Osteolepiforms and the ancestry of tetrapods. Nature 395:792-793.

Ahlberg, P. E., Z. Johanson, and E. B. Daeschler. 2001. The Late Devonian lungfish Soederberghia (Sarcopterygii, Dipnoi) from Australia and North America, and its biogeographical implications. Journal of Vertebrate Paleontology 21:1-12.

Andrews, S. M., and T. S. Westoll. 1970. The postcranial skeleton of Eusthenopteron foordi Whiteaves. Transactions of the Royal Society of Edinburgh: Earth Sciences 68:207329.

Berg, L. S. 1937. A classification of fish-like vertebrates. Bulletin of the Academy of Sciences of USSR, Class of Mathematics and Natural Sciences, Biological Series 1237-1277.

Béthune, P. de. 1954. Carte Géologique de Belgique (échelle 1/500.000); Atlas de Belgique. Académie Royale de Belgique.

Borgen, U. J., and H. A. Nakrem. 2016. Morphology, phylogeny and taxonomy of osteolepiform fish. Fossils and Strata 61:1-514.

Clément, G. 2002. Large Tristichopteridae (Sarcopterygii, Tetrapodomorpha) from the Late Famennian Evieux Formation of Belgium. Palaeontology 45:577-593. 
Clément, G., and C. A. Boisvert. 2006. Lohest's true and false 'Devonian amphibians': evidence for the rhynchodipterid lungfish Soederberghia in the Famennian of Belgium. Journal of Vertebrate Paleontology 26:276-283.

Clément, G., D. Snitting, and P. E. Ahlberg. 2009. A new tristichopterid (Sarcopterygii, Tetrapodomorpha) from the Upper Famennian Evieux Formation (Upper Devonian) of Belgium. Palaeontology 52:823-836.

Clément, G., P. E. Ahlberg, A. Blieck, H. Blom, J. A. Clack, E. Poty, J. Thorez, and P. Janvier. 2004. Palaeogeography: Devonian tetrapod from western Europe. Nature $427: 412-413$.

Cloutier, R., and P. E. Ahlberg. 1996. Morphology, characters, and the interrelationships of basal sarcopterygians; pp. 445-480 in M. L. J. Stiassny, L. R. Parenti, and G. D. Johnson, G (eds.), Interrelationships of fishes. Academic Press, San diego, California.

Cloutier, R., and A. -M. Candilier. 1995. Palaeozoic vertebrates of northern France and Belgium: Part III - Sarcopterygii (Devonian to Carboniferous). Geobios Mémoire spécial 19:335-342.

Cope, E. D. 1887. Zittel's Manual of Palaeontology. The American Naturalist 21:1014-1020.

Daeschler, E. B., and J. P. Downs. 2018. New description and diagnosis of Hyneria lindae (Sarcopterygii, Tristichopteridae) from the Upper Devonian Catskill Formation in Pennsylvania, USA. Journal of Vertebrate Paleontology:e1448834.

Daeschler, E. B., and N. H. Shubin. 2007. New data on Hyneria lindae (Sarcopterygii, Tristichopteridae) from the Late Devonian of Pennsylvania, USA. Journal of Vertebrate Paleontology 27 (3, Supplement):65A.

Davesne, D., J. Mondéjar-Fernández, V. Hairapetian, M. Rücklin, J. Wendt, and G. Clément. 2015. A new large tetrapodomorph sarcopterygian from the Late Devonian of Iran. Paläontologische Zeitschrift 89:661-667. 
Denayer, J., C. Prestianni, P. Gueriau, S. Olive, and G. Clément. 2016. Stratigraphy and depositional environments of the Late Famennian (Late Devonian) of Southern Belgium and characterization of the Strud locality. Geological Magazine 153:112127.

Downs, J. P., E. B. Daeschler, A. M. Long, and N. H. Shubin. 2018. Eusthenopteron jenkinsi sp. nov. (Sarcopterygii, Tristichopteridae) from the Upper Devonian of Nunavut, Canada, and a review of Eusthenopteron taxonomy). Breviora 562:1-24.

Egerton, P. de M. G. 1861. Tristichopterus alatus; pp. 51-55 in Figures and Descriptions Illustrative of British Organic Remains. Memoirs of the Geological Survey of the United Kingdom 10.

Holland, T., and J. A. Long. 2009. On the phylogenetic position of Gogonasus andrewsae Long 1985, within the Tetrapodomorpha. Acta Zoologica, Supplement 1, 90:285-96. Janvier, P., and G. Clément. 2005. A new groenlandaspidid Arthrodire (Vertebrata: Placodermi) from the Famennian of Belgium. Geologica Belgica 8:51-67 Janvier, P. and J. G. Maisey. 2010. The Devonian vertebrates of South America and their biogeographical relationships. pp.431-459 in D. K. Elliott, J. G. Maisey, X. Yu and D. Miao (eds.), Morphology, phylogeny and paleobiogeography of fossil fishes. Verlag Dr. Friedrich Pfeil. München, Germany.

Janvier, P., and C. Villarroel. 2000. Devonian vertebrates from Colombia. Palaeontology 43:729-763.

Jarvik, E. 1944a. On the dermal bones, sensory canals and pit-lines of the skull in Eusthenopteron foordi Whiteaves, with some remarks on E. save-soderberghi Jarvik. Kungliga Svenska VetenskapsAkademiens Handlingar 21:1-48. 
Jarvik, E. 1944b. On the exoskeletal shoulder-girdle of teleostomian fishes, with special reference to Eusthenopteron foordi Whiteaves. Kungliga Svenska Vetenskapsakademiens Handlingar 21:1-32.

Jarvik, E. 1952. On the fish-like tail in the ichthyostegid stegocephalians with descriptions of a new stegocephalian and a new crossopterygian from the Upper Devonian of East Greenland. Meddelelser om Grønland 114:1-90.

Jarvik, E. 1985. Devonian osteolepiform fishes from East Greenland. Meddelelser om Grønland, Geoscience 13:1-52.

Johanson, Z. 2004. Late Devonian sarcopterygian fishes from eastern Gondwana (Australia and Antarctica) and their importance in phylogeny and biogeography. pp. 287-308 in G. Arratia, M. V. H. Wilson, and R. Cloutier (eds.), Recent Advances in the Origin and Early Radiation of Vertebrates. Verlag Dr. Friedrich Pfeil. München, Germany.

Johanson, Z., and P. E. Ahlberg. 1997. A new tristichopterid (Osteolepiformes:

Sarcopterygii) from the Mandagery Sandstone (Late Devonian, Famennian) near Canowindra, NSW, Australia. Transactions of the Royal Society of Edinburgh: Earth Sciences 88:39-68.

Johanson, Z., and P. E. Ahlberg. 2001. Devonian rhizodontids and tristichopterids (Sarcopterygii; Tetrapodomorpha) from East Gondwana. Transactions of the Royal Society of Edinburgh: Earth Sciences 92:43-74.

Lehman, J. -P. 1977. Sur la présence d'un ostéolépiforme dans le Dévonien supérieur du Tafilalet. Comptes Rendus de l'Académie des Sciences, Série D, Sciences naturelles 285:151-153.

Lelièvre, H., and P. Janvier. 1986. L'eusthénoptéridé (Osteichthyes, Sarcopterygii) du Famennien (Dévonien supérieur) du Tafilalet (Maroc): nouvelle description. Bulletin 
du Muséum National d'Histoire Naturelle, Section C, Sciences de la terre, paléontologie, géologie, minéralogie 3:351-365.

Lelièvre, H., P. Janvier, and A. Blieck. 1993. Silurian-Devonian vertebrate biostratigraphy of Western Gondwana and related terranes (South America, Africa, Armorica-Bohemia, Middle East); pp. 139-173 in J. A. Long (ed.), Palaeozoic Vertebrate Biostratigraphy and Biogeography, Belhaven Press, London.

Leriche, M. 1931. Les poissons famenniens de la Belgique. Les faciès du Famennien dans la région gallo-belge. Les relations entre les formations marines et les formations continentales du Dévonien supérieur sur la bordure méridionale du Continent NordAtlantique. Mémoires de l'Académie Royale de Belgique Classe des Sciences 10:1-72.

Lohest, M. 1888. Recherches sur les poissons des terrains paléozoïques de Belgique.

Poissons des Psammites du Condroz, Famennien supérieur. Annales de la Société Géologique de Belgique Mémoire 15:112-203.

Long, J. A. 1985a. A new osteolepidid fish from the Upper Devonian Gogo Formation of Western Australia. Records of the Western Australian Museum 12:361-377.

Long, J. A. 1985b. The structure and relationships of a new osteolepiform fish from the Late Devonian of Victoria, Australia. Alcheringa 9:1-22.

Long, J. A., G. C. Young, T. Holland, T. J. Senden, and E. M. G. Fitzgerald. 2006. An exceptional Devonian fish from Australia sheds light on tetrapod evolution. Nature 444:199-202.

Olive, S. 2015. Devonian antiarch placoderms from Belgium revisited. Acta Palaeontologica Polonica 60:711-731.

Olive, S., G. Clément, E. B. Daeschler, and V. Dupret. 2015b. Characterization of the placoderm (Gnathostomata) assemblage from the tetrapod-bearing locality of Strud (Belgium, Upper Famennian). Palaeontology 58:981-1002. 
Olive, S., G. Clément, E. B. Daeschler, and V. Dupret. 2016b. Placoderm assemblage from the tetrapod-bearing locality of Strud (Belgium, Upper Famennian) provides evidence for a fish nursery. PLoS ONE 11:e0161540.

Olive, S., P. E. Ahlberg, V. N. Pernègre, E. Poty, E. Steurbaut, and G. Clément. 2016a. New discoveries of tetrapods (ichthyostegid-like and whatcheeriid-like) in the Famennian (Late Devonian) localities of Strud and Becco (Belgium). Palaeontology 59:827-840.

Olive, S., G. Clément, J. Denayer, C. Derycke, V. Dupret, P. Gerrienne, P. Gueriau, J. -M. Marion, B. Mottequin, and C. Prestianni. 2015a. Flora and fauna from a new Famennian (Upper Devonian) locality at Becco, eastern Belgium. Geologica Belgica 18:92-101.

Olive, S., A. Pradel, C. Martinez-Perez, J. Lamsdell, P. Gueriau, N. Rabet, P. DuranleauGagnon, P. Janvier, A. L. Cardenas, P. A. Zapata-Ramirez, and H. Botella. In review. New insights into Devonian vertebrates from Colombia and associate fauna. Journal of Vertebrate Paleontology.

Romer, A. S. 1955. Herpetichthyes, Amphibioidei, Choanichthyes or Sarcopterygii? Nature 176:126.

Ronquist, F., and J. P. Huelsenbeck. 2003. MrBayes3: Bayesian phylogenetic inference undermixed models. Bioinformatics 19:1572-1574.

Schultze, H. -P., and J. W. Reed. 2012. A tristichopterid sarcopterygian fish from the upper Middle Devonian of Nevada. Historical Biology 24:425-440.

Scotese, C. R. 2014. Atlas of Devonian paleogeographic maps, PALEOMAP atlas for ArcGIS, 4, the Late Paleozoic, Maps 65-72, Mollweide Projection, PALEOMAP Project, Evanston, Illinois. 
Snitting, D. 2008a. Morphology, taxonomy and interrelationships of tristichopterid fishes (Sarcopterygii, Tetrapodomorpha). Ph.D. dissertation, Acta Universitatis Upsaliensis, Uppsala, Sweden, 54 pp.

Snitting, D. 2008b. A redescription of the anatomy of the Late Devonian Spodichthys buetleri Jarvik, 1985 (Sarcopterygii, Tetrapodomorpha) from East Greenland. Journal of Vertebrate Paleontology 28:637-655.

Snitting, D. 2009. Heddleichthys - a new tristichopterid genus from the Dura Den Formation, Midland Valley, Scotland (Famennian, Late Devonian). Acta Zoologica 90(1, Supplement):273-284.

Swartz, B. 2012. A marine stem-tetrapod from the Devonian of western North America. PLoS ONE 7:e33683.

Swofford, D. L. 2002. PAUP*: phylogenetic analysis using parcimony (and other methods). Version 4.0a62. http://phylosolutions.com/paup-test/

Thorez, J., and R. Dreesen. 1986. A model of regressive depositional system around the Old Red Continent as exemplified by a field trip in the Upper Famennian 'Psammites du Condroz’ in Belgium. Annales de la Société géologique de Belgique 109:285-323.

Thorez, J., R. Dreesen, and M. Streel. 2006. Famennian; pp. 27-45 in L. Dejonghe (ed.), Current status of chronostratigraphic units named from Belgium and adjacent areas. Geologica Belgica 9.

Vorobyeva, E. I. 1959. A new crossopterygian fish genus Platycephalichthys from the Upper Devonian of the Lovat River. Paleontologicheskii Zhurnal, Acd. Sci. U.S.S.R. 3:95106. [Russian]

Vorobyeva, E. I. 1962. Rhizodontid crossopterygians of the main Devonian field of the USSR. Trudy Paleontologicheskogo Instituta, Akademii Nauk SSSR 94:1-139. [Russian] 
Young, G. C. 2008. Relationships of tristichopterids (osteolepiform lobe-finned fishes) from the Middle-Late Devonian of East Gondwana. Alcheringa 32:321-336.

Young, G. C., J. A. Long, and A. Ritchie. 1992. Crossopterygian fishes from the Devonian of Antarctica: systematics, relationships and biogeographic significance. Records of the Australian Museum Supplement 14:1-77.

Young, B., R. L. Dunstone, T. J. Senden, and G. C. Young. 2013. A Gigantic Sarcopterygian (Tetrapodomorph Lobe-Finned Fish) from the Upper Devonian of Gondwana (Eden, New South Wales, Australia). PLoS ONE 8:e53871.

Yu, Y., A. J. Harris, C. Blair, and X. J. He. 2015. RASP (Reconstruct Ancestral State in Phylogenies): a tool for historical biogeography. Molecular Phylogenetics and Evolution 87:46-49.

Zhu, M., and P. E. Ahlberg. 2004. The origin of the internal nostril of tetrapods. Nature 432:94-97.

Ziegler, P. A. 1990. Geological atlas of Western and Central Europe, Second edition. Shell Internationale Petroleum Maatschappij B.V., and Geological Society of London, Avon, 239 pp.

Submitted April 5th, 2019; revisions received Month DD, YYYY; accepted Month DD, YYYY 


\section{Figure Captions}

FIGURE 1. Geographical and geological localizations of Belgian tristichopterid localities including Strud (Namur Province). A, Geographic localities; B, Geological map of Southern Belgium, modified from Denayer et al. (2016), redrawn from Béthune (1954); C, schematic block diagram of the Strud channel with the location of tristichopterid remains, modified from Denayer et al (2016). [planned for page width]

FIGURE 2. cf. Langlieria socqueti, Strud, Belgium, late Famennian. A, left squamosal, internal view, IRSNB P 9912, photograph; B, left squamosal, imprint of the external surface (bone removed), IRSNB P 9912, photograph; C, left squamosal, external view, IRSNB P 9912, interpretative drawing; D, right mandible, external view, IRSNB P 9913, photograph; E, right mandible, external view, IRSNB P 9913, interpretative drawing; F, right mandible, external view, IRSNB P 9913, close-up photograph on the symphysis. Scale bars equal $1 \mathrm{~cm}$. [planned for page width]

FIGURE 3. cf. Eusthenodon wangsjoi, Strud, Belgium, Upper Famennian. A, incomplete left parietal, external view, IRSNB P 9910, photograph; B, incomplete left parietal, external view, IRSNB P 9910, interpretative drawing; C-D, left supratemporal, external and visceral views, IRSNB P 9914, photographs; E-F, left supratemporal, external and visceral views, IRSNB P 9914, interpretative drawings; G, left postorbital, external view, IRSNB P 9915, photograph; H, left postorbital, external view, IRSNB P 9915, interpretative drawing; I-J, left preopercular, external and visceral views, IRSNB P 9916, photographs; K, left opercular, external view, IRSNB P 9917, photograph; L, left opercular, external view, IRSNB P 9917, 
interpretative drawing. Black arrow points anteriorly. Scale bars: A-H equal $1 \mathrm{~cm}, \mathbf{I}-\mathbf{L}$ equal $2 \mathrm{~cm}$. [planned for page width]

FIGURE 4. cf. Eusthenodon wangsjoi, Strud, Belgium, late Famennian. A, right dentary, external view, IRSNB P 9918, 3D reconstruction; B, right dentary, visceral view, IRSNB P 9918, 3D reconstruction; C, right mandible, external view, IRSNB P 9919, 3D reconstruction; D, right mandible, visceral view, IRSNB P 9919, 3D reconstruction; E, coronoids, external view, IRSNB P 9919, 3D reconstruction; F, coronoids, apical view, IRSNB P 9919, 3D reconstruction. Left white arrow indicates putative suture between the infradentaries 3 and 4, right white arrow indicates pit line of infradentary 2. Black arrow points anteriorly. Scale bars: A-B, E-F equal $1 \mathrm{~cm}, \mathbf{C}-\mathbf{D}$ equal $2 \mathrm{~cm}$. [planned for page width]

FIGURE 5. cf. Tristichopteridae indet., Strud, Belgium, Upper Famennian. A, right preopercular, external view, IRSNB P 9920, photograph; B, left subopercular, visceral view, IRSNB P 9921, photograph; C, left subopercular, visceral view, IRSNB P 9922, photograph; D, left subopercular, visceral view, IRSNB P 9923, photograph; E, right palatoquadrate, visceral view, IRSNB P 9911, photograph; F, right palatoquadrate, visceral view, IRSNB P 9911, interpretative drawing. Black arrow points anteriorly. Scale bars equal $1 \mathrm{~cm}$. [planned for page width]

FIGURE 6. cf. Tristichopteridae indet., Strud, Belgium, Upper Famennian. A, right cleithrum, visceral view, IRSNB P 9924, photograph; B, right cleithrum, imprint of the external view (bone removed), IRSNB P 9924, photograph; C-D, right cleithrum, external and visceral views, IRSNB P 9925, photographs; E, incomplete right cleithrum, visceral 
view, IRSNB P 9926, photograph; F, incomplete right cleithrum, visceral view, IRSNB P 9927, photograph; G, isolated fang, labial or lingual view, IRSNB P 9928, photograph; H, isolated fang, labial or lingual view, IRSNB P 9929, photograph; I, isolated scale, visceral view, IRSNB P 9930, photograph; J, isolated scale, visceral view, IRSNB P 9931, photograph; K, isolated scale, visceral view, IRSNB P 9932, photograph; $\mathbf{L}$, isolated scale, visceral view, IRSNB P 9933, photograph. Scale bars equal $1 \mathrm{~cm}$. [planned for page width]

FIGURE 7. Strict consensus tree showing phylogenetic relationships of the Tristichopteridae, with maximum parsimony biogeographic reconstruction result using Bayesian Binary MCMC analysis mapped on. The number in the center of each pie chart corresponds to the node number. The pie chart over each node represents the probability that the clade originated from each continental area. The numbers on the top of each pie chart correspond to the Bremer index (in italics) and to the minimal and maximal number of synapomorphies at each node (in bold). Some character state changings have been reported on the branches. GIV for Givetian, FRAS for Frasnian and FAM for Famennian. [planned for page width]

SUPPLEMENTAL INFORMATION 1. List of characters considered in the phylogenetic analysis.

SUPPLEMENTAL INFORMATION 2. Matrix of characters considered in the phylogenetic analysis.

SUPPLEMENTAL INFORMATION 3. Details of the phylogenetic analysis.

SUPPLEMENTAL INFORMATION 4. Taxon geographical distribution. 
SUPPLEMENTAL INFORMATION 5. Results of the maximum parsimony biogeographic reconstructions using Bayesian Binary MCMC analysis.

SUPPLEMENTARY INFORMATION 6: 3D PDF of a right dentary of Eusthenodon wangsjoi. Strud, Belgium, late Famennian. IRSNB P 9918. Click to activate in the PDF version.

SUPPLEMENTARY INFORMATION 7: 3D PDF of a right mandible of Eusthenodon wangsjoi. Strud, Belgium, late Famennian. IRSNB P 9919. Click to activate in the PDF version. 

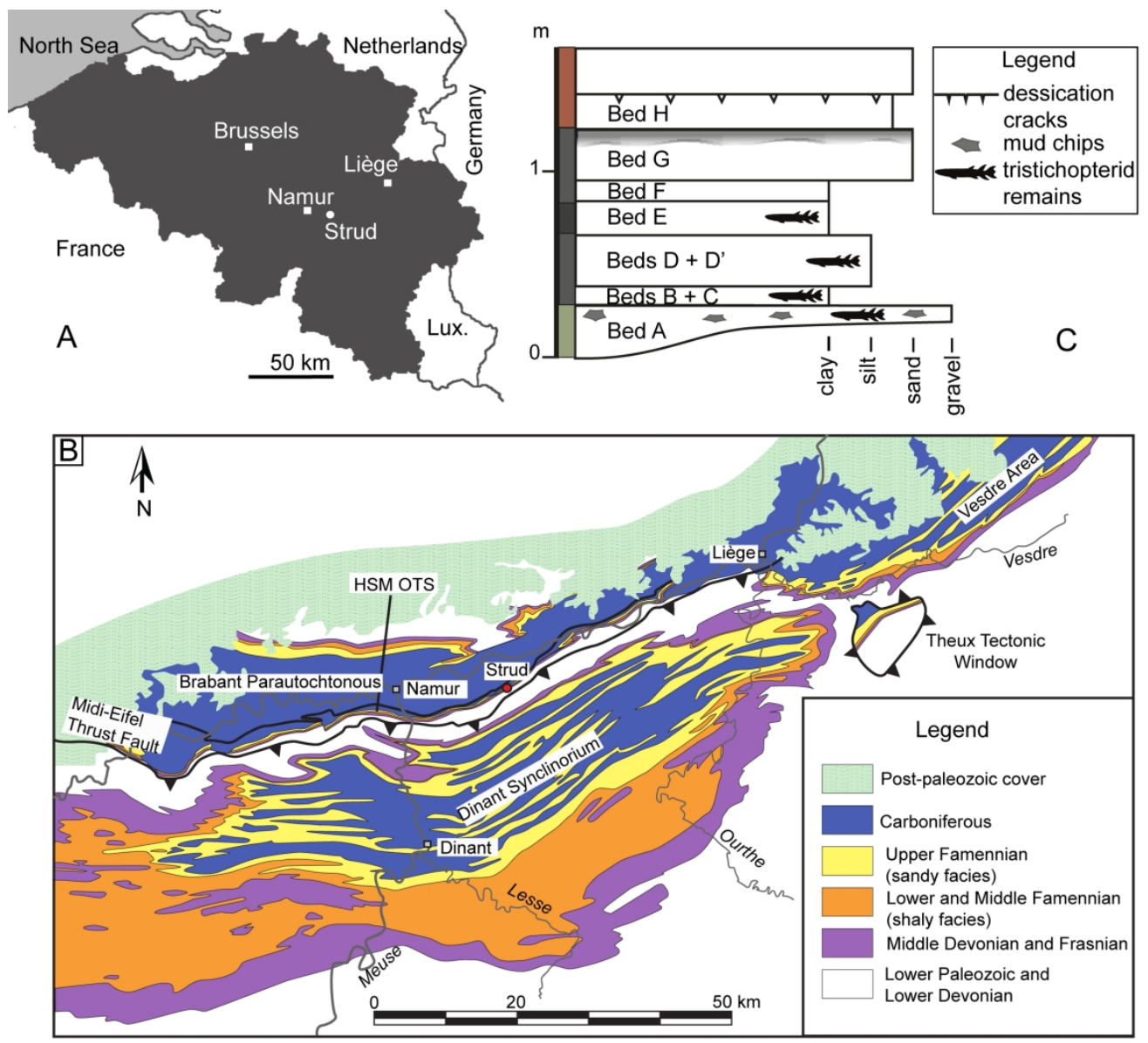

FIGURE 1. Geographical and geological localizations of Belgian tristichopterid localities including Strud (Namur Province). A, Geographic localities; B, Geological map of Southern Belgium, modified from Denayer et al. (2016), redrawn from Béthune (1954); C, schematic block diagram of the Strud channel with the location of tristichopterid remains, modified from Denayer et al (2016). [planned for page width]

$180 \times 163 \mathrm{~mm}(300 \times 300 \mathrm{DPI})$ 


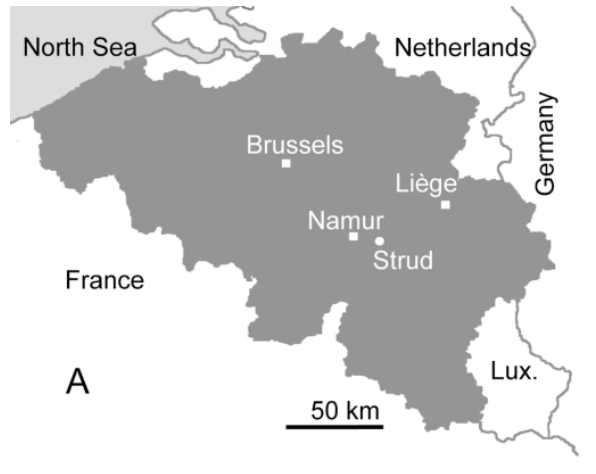

m

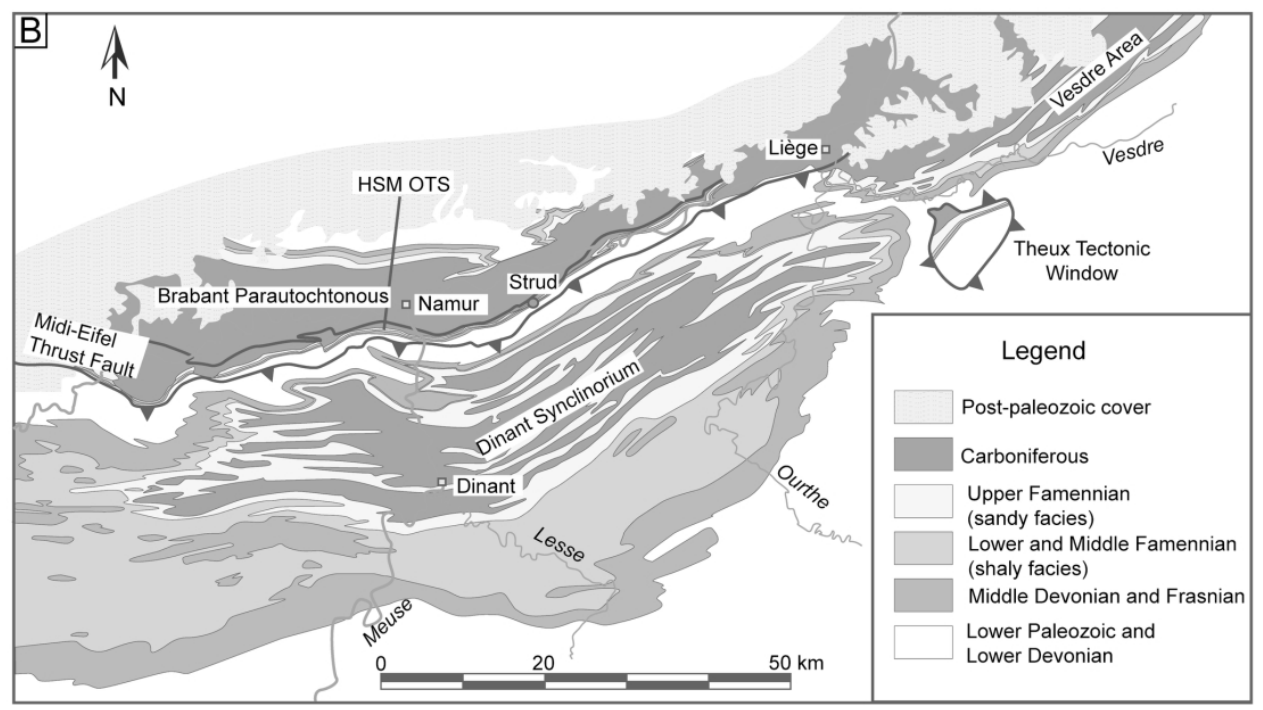

FIGURE 1. Geographical and geological localizations of Belgian tristichopterid localities including Strud (Namur Province). A, Geographic localities; B, Geological map of Southern Belgium, modified from Denayer et al. (2016), redrawn from Béthune (1954); C, schematic block diagram of the Strud channel with the location of tristichopterid remains, modified from Denayer et al (2016). [planned for page width]

$180 \times 163 \mathrm{~mm}(300 \times 300 \mathrm{DPI})$ 

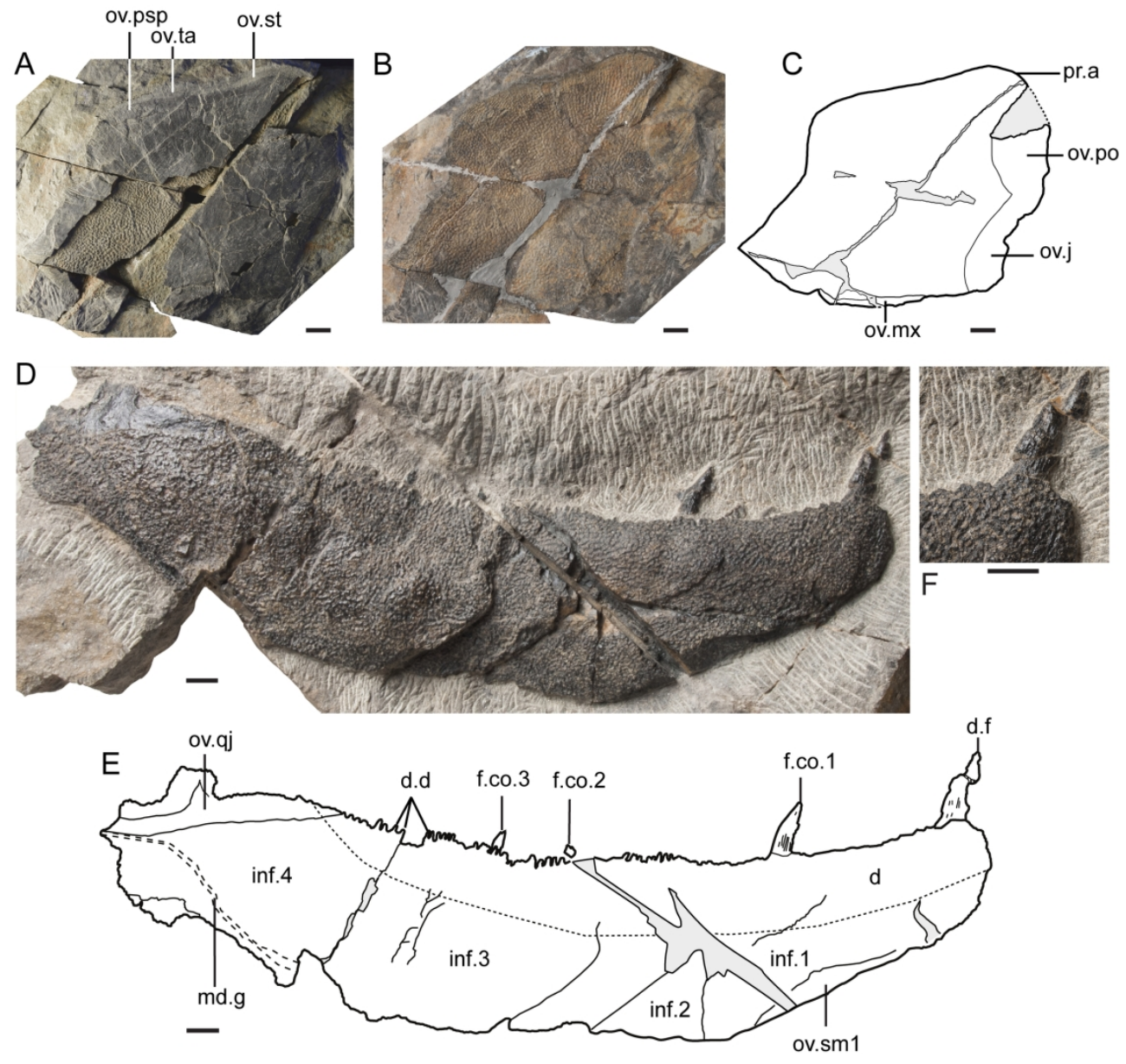

FIGURE 2. cf. Langlieria socqueti, Strud, Belgium, late Famennian. A, left squamosal, internal view, IRSNB P 9912, photograph; B, left squamosal, imprint of the external surface (bone removed), IRSNB P 9912, photograph; C, left squamosal, external view, IRSNB P 9912, interpretative drawing; D, right mandible, external view, IRSNB P 9913, photograph; E, right mandible, external view, IRSNB P 9913, interpretative drawing; F, right mandible, external view, IRSNB P 9913, close-up photograph on the symphysis. Scale bars equal $1 \mathrm{~cm}$. [planned for page width]

$$
181 \times 176 \mathrm{~mm}(300 \times 300 \text { DPI) }
$$



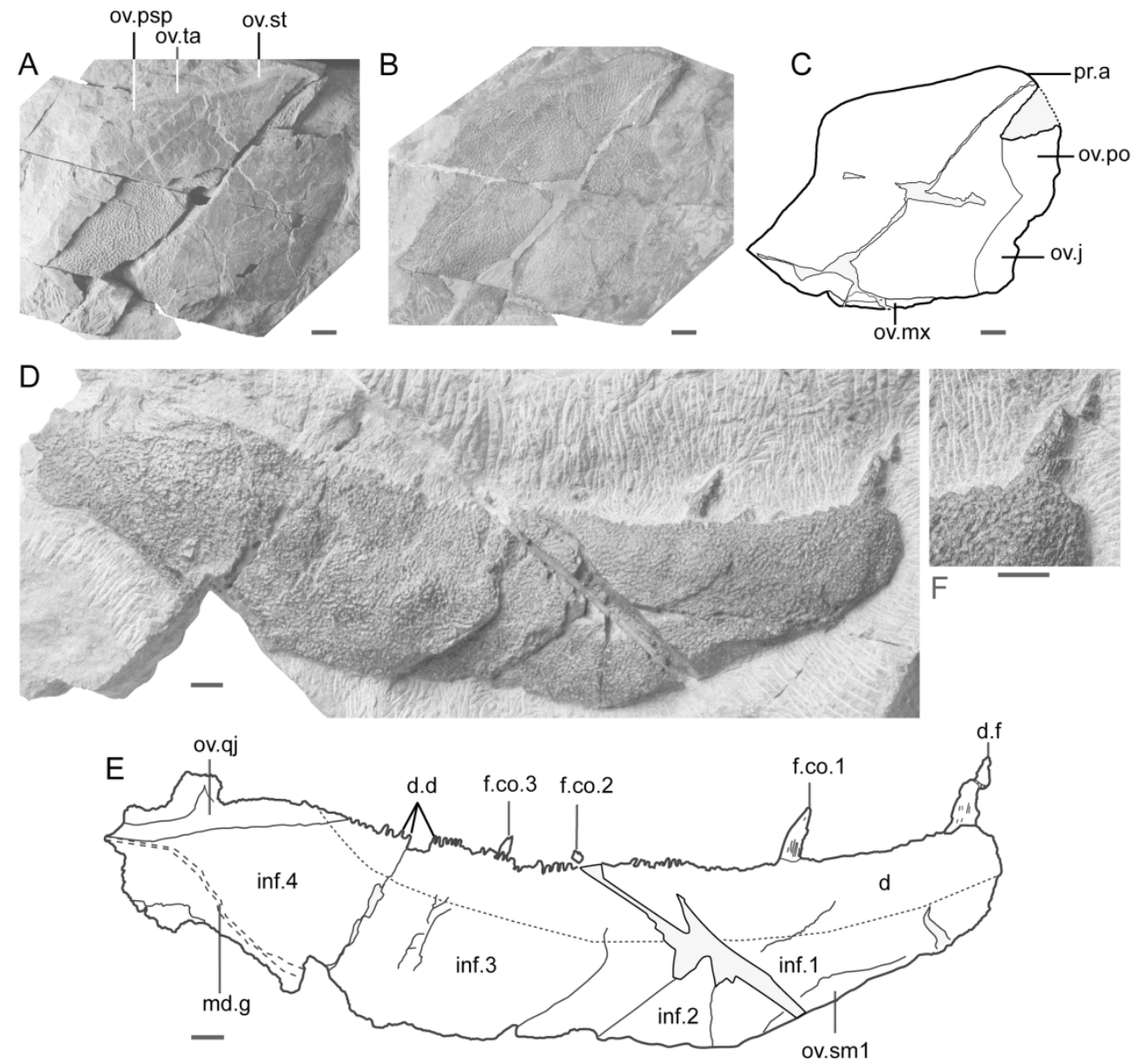

FIGURE 2. cf. Langlieria socqueti, Strud, Belgium, late Famennian. A, left squamosal, internal view, IRSNB P 9912, photograph; B, left squamosal, imprint of the external surface (bone removed), IRSNB P 9912, photograph; C, left squamosal, external view, IRSNB P 9912, interpretative drawing; D, right mandible, external view, IRSNB P 9913, photograph; E, right mandible, external view, IRSNB P 9913, interpretative drawing; F, right mandible, external view, IRSNB P 9913, close-up photograph on the symphysis. Scale bars equal $1 \mathrm{~cm}$. [planned for page width]

$$
181 \times 176 \mathrm{~mm}(300 \times 300 \mathrm{DPI})
$$


FIGURE 3. cf. Eusthenodon wangsjoi, Strud, Belgium, Upper Famennian. A, incomplete left parietal, external view, IRSNB P 9910, photograph; B, incomplete left parietal, external view, IRSNB P 9910, interpretative drawing; C-D, left supratemporal, external and visceral views, IRSNB P 9914, photographs; E-F, left supratemporal, external and visceral views, IRSNB P 9914, interpretative drawings; G, left postorbital, external view, IRSNB P 9915, photograph; H, left postorbital, external view, IRSNB P 9915, interpretative drawing; I-J, left preopercular, external and visceral views, IRSNB P 9916, photographs; K, left opercular, external view, IRSNB P 9917, photograph; L, left opercular, external view, IRSNB P 9917, interpretative drawing. Black arrow points anteriorly. Scale bars: A-H equal $1 \mathrm{~cm}, \mathrm{I}-\mathrm{L}$ equal $2 \mathrm{~cm}$. [planned for page width]

$184 \times 260 \mathrm{~mm}(300 \times 300 \mathrm{DPI})$ 
FIGURE 3. cf. Eusthenodon wangsjoi, Strud, Belgium, Upper Famennian. A, incomplete left parietal, external view, IRSNB P 9910, photograph; B, incomplete left parietal, external view, IRSNB P 9910, interpretative drawing; C-D, left supratemporal, external and visceral views, IRSNB P 9914, photographs; E-F, left supratemporal, external and visceral views, IRSNB P 9914, interpretative drawings; G, left postorbital, external view, IRSNB P 9915, photograph; $H$, left postorbital, external view, IRSNB P 9915, interpretative drawing; I-J, left preopercular, external and visceral views, IRSNB P 9916, photographs; K, left opercular, external view, IRSNB P 9917, photograph; L, left opercular, external view, IRSNB P 9917, interpretative drawing. Black arrow points anteriorly. Scale bars: A-H equal $1 \mathrm{~cm}$, I-L equal $2 \mathrm{~cm}$. [planned for page width]

$184 \times 260 \mathrm{~mm}(300 \times 300 \mathrm{DPI})$ 

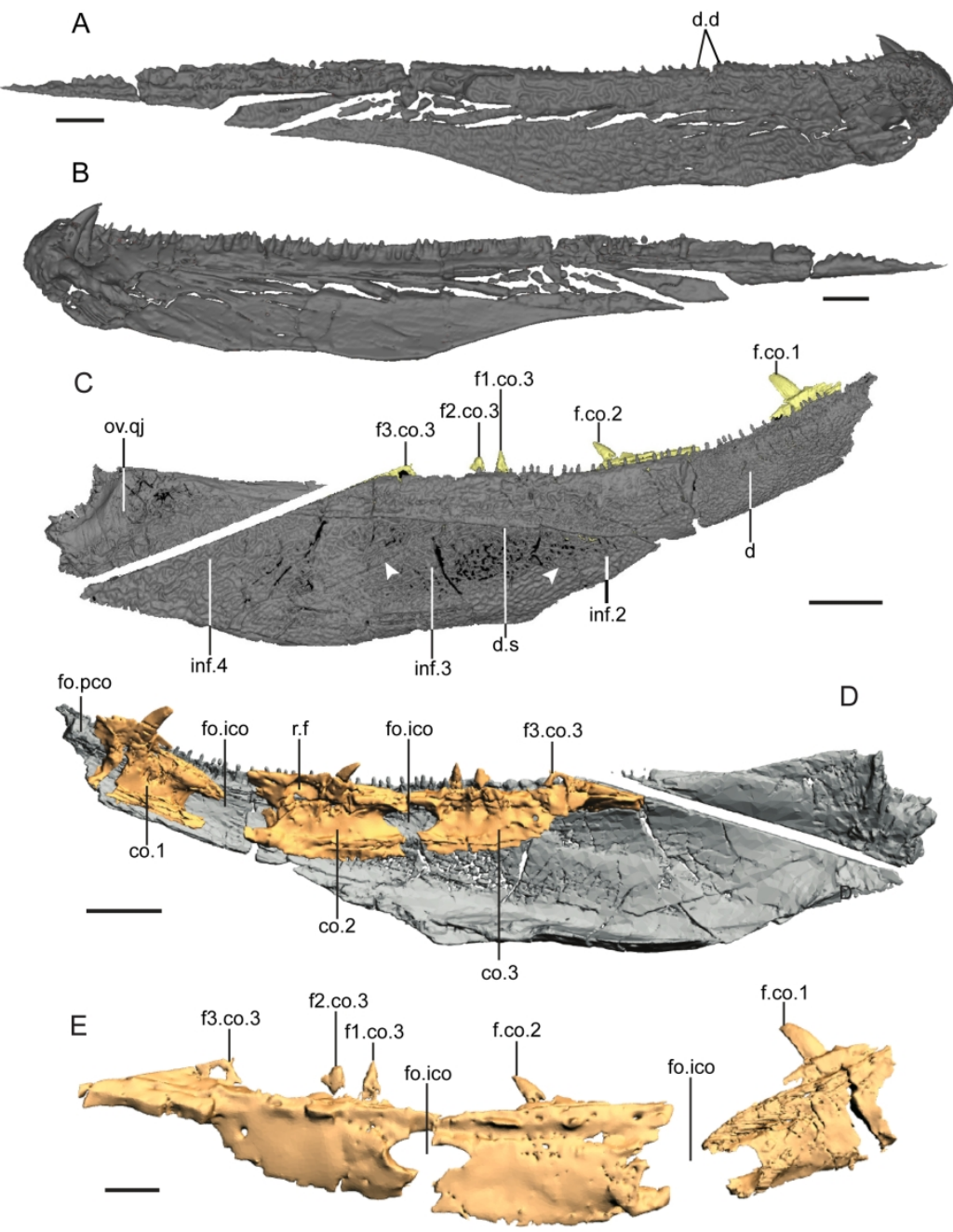

$\mathrm{F}$

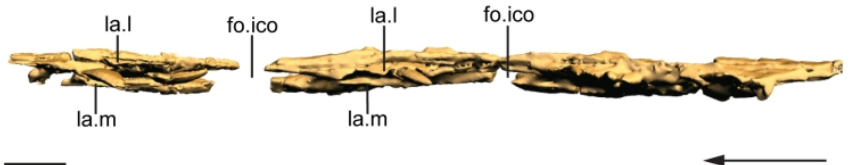

FIGURE 4. cf. Eusthenodon wangsjoi, Strud, Belgium, late Famennian. A, right dentary, external view, IRSNB P 9918, 3D reconstruction; B, right dentary, visceral view, IRSNB P 9918, 3D reconstruction; C, right mandible, external view, IRSNB P 9919, 3D reconstruction; D, right mandible, visceral view, IRSNB P 9919, 3D reconstruction; E, coronoids, external view, IRSNB P 9919, 3D reconstruction; F, coronoids, apical view, IRSNB P 9919, 3D reconstruction. Left white arrow indicates putative suture between the infradentaries 3 and 4, right white arrow indicates pit line of infradentary 2. Black arrow points anteriorly. Scale bars: A-B, $\mathrm{E}-\mathrm{F}$ equal $1 \mathrm{~cm}, \mathrm{C}-\mathrm{D}$ equal $2 \mathrm{~cm}$. [planned for page width]

$181 \times 257 \mathrm{~mm}(300 \times 300 \mathrm{DPI})$ 

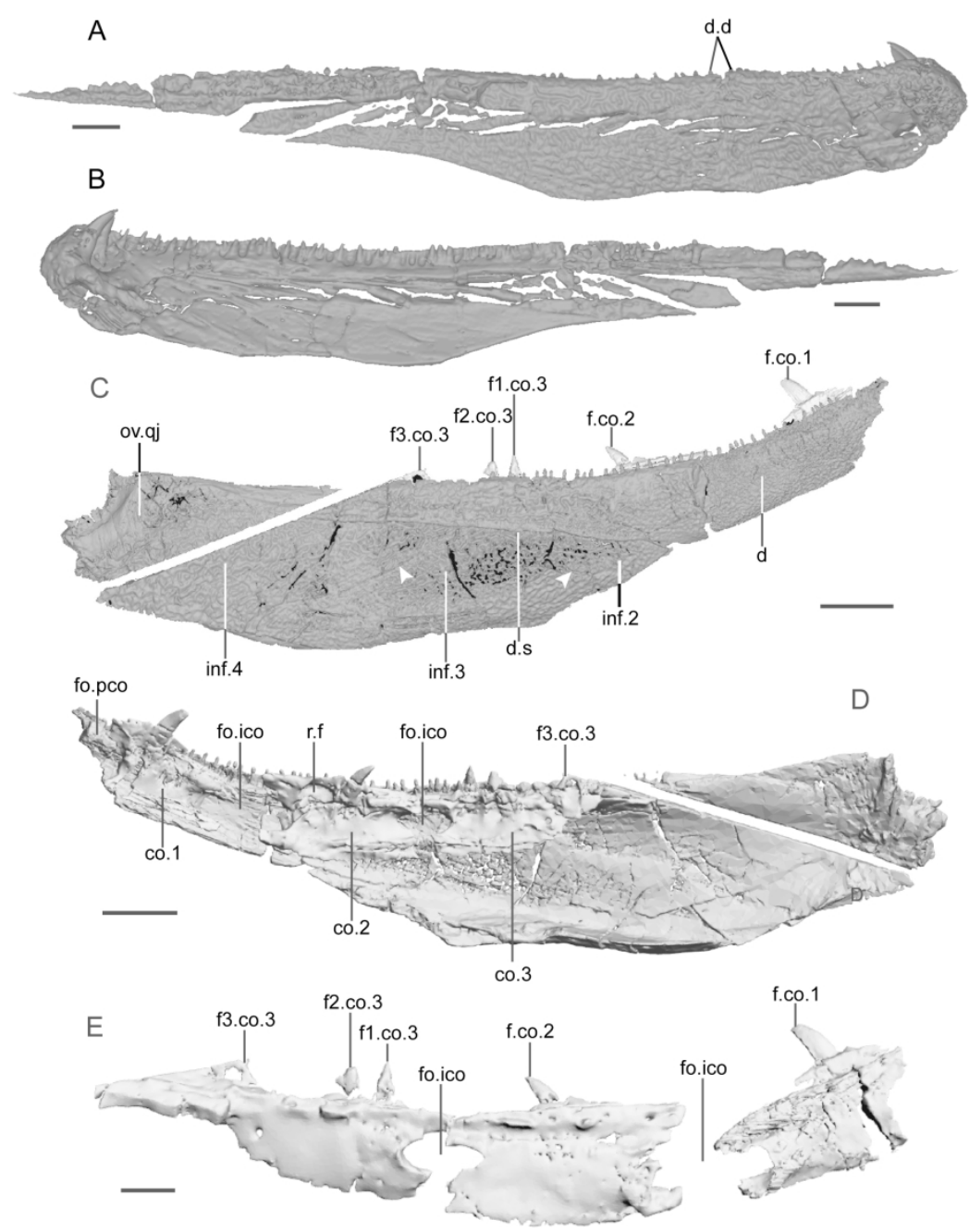

F

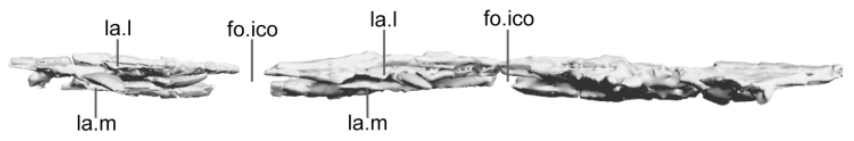

FIGURE 4. cf. Eusthenodon wangsjoi, Strud, Belgium, late Famennian. A, right dentary, external view, IRSNB P 9918, 3D reconstruction; B, right dentary, visceral view, IRSNB P 9918, 3D reconstruction; C, right mandible, external view, IRSNB P 9919, 3D reconstruction; D, right mandible, visceral view, IRSNB P 9919, 3D reconstruction; E, coronoids, external view, IRSNB P 9919, 3D reconstruction; F, coronoids, apical view, IRSNB P 9919, 3D reconstruction. Left white arrow indicates putative suture between the infradentaries 3 and 4, right white arrow indicates pit line of infradentary 2. Black arrow points anteriorly. Scale bars: A-B, $\mathrm{E}-\mathrm{F}$ equal $1 \mathrm{~cm}, \mathrm{C}-\mathrm{D}$ equal $2 \mathrm{~cm}$. [planned for page width]

$181 \times 257 \mathrm{~mm}(300 \times 300 \mathrm{DPI})$ 

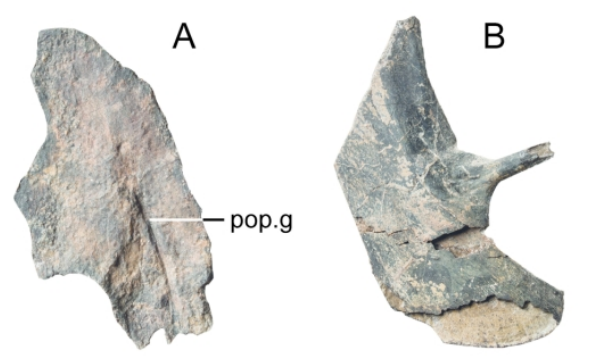

C
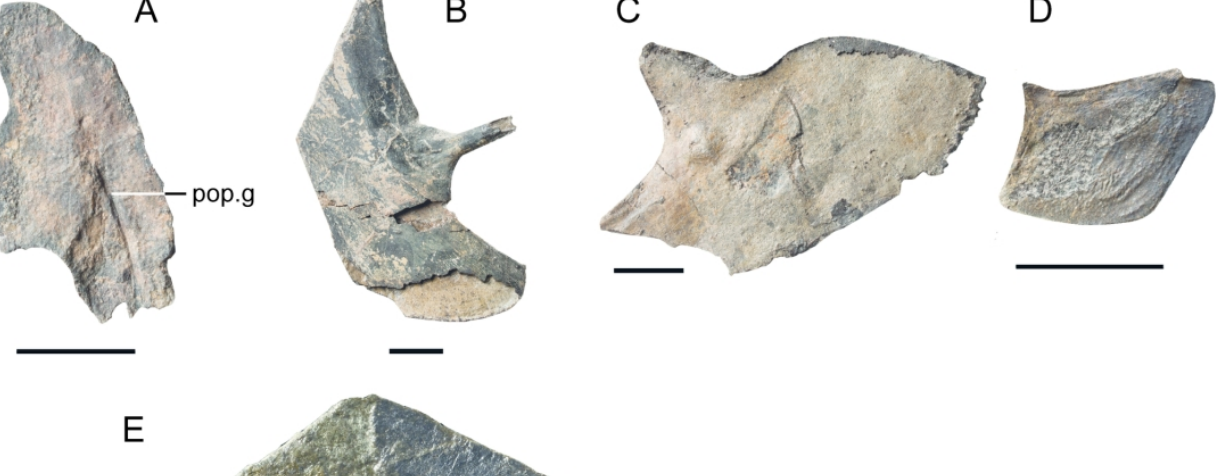

E

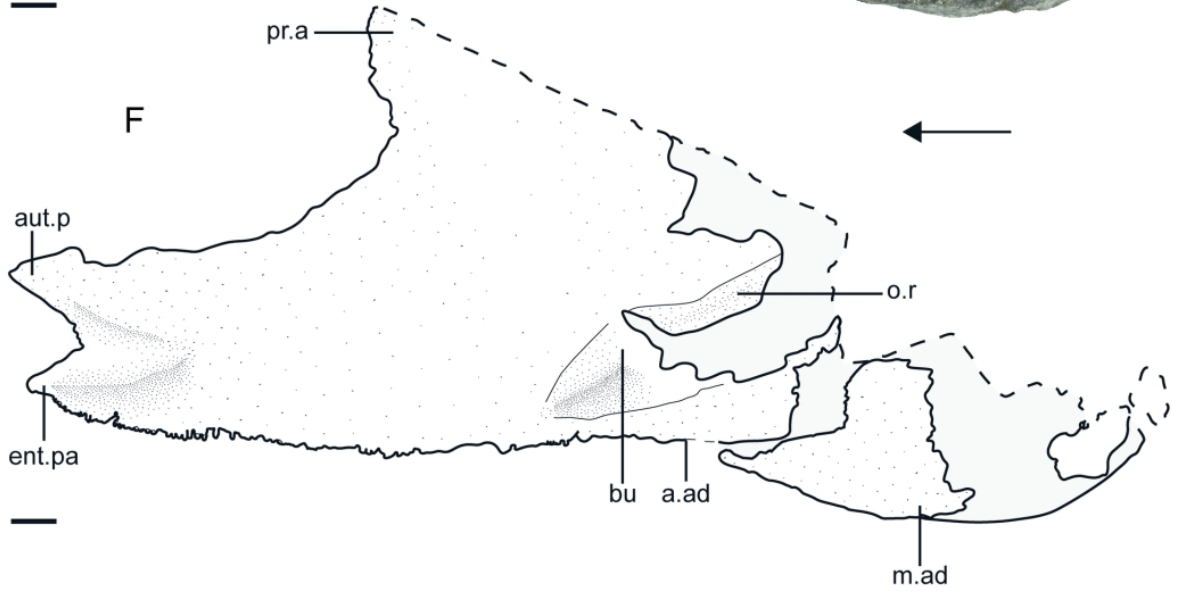

FIGURE 5. cf. Tristichopteridae indet., Strud, Belgium, Upper Famennian. A, right preopercular, external view, IRSNB P 9920, photograph; B, left subopercular, visceral view, IRSNB P 9921, photograph; C, left subopercular, visceral view, IRSNB P 9922, photograph; D, left subopercular, visceral view, IRSNB P 9923, photograph; E, right palatoquadrate, visceral view, IRSNB P 9911, photograph; F, right palatoquadrate, visceral view, IRSNB P 9911, interpretative drawing. Black arrow points anteriorly. Scale bars equal $1 \mathrm{~cm}$. [planned for page width]

$181 \times 213 \mathrm{~mm}(300 \times 300 \mathrm{DPI})$ 
FIGURE 5. cf. Tristichopteridae indet., Strud, Belgium, Upper Famennian. A, right preopercular, external view, IRSNB P 9920, photograph; B, left subopercular, visceral view, IRSNB P 9921, photograph; C, left subopercular, visceral view, IRSNB P 9922, photograph; D, left subopercular, visceral view, IRSNB P 9923, photograph; E, right palatoquadrate, visceral view, IRSNB P 9911, photograph; F, right palatoquadrate, visceral view, IRSNB P 9911, interpretative drawing. Black arrow points anteriorly. Scale bars equal $1 \mathrm{~cm}$. [planned for page width]

$181 \times 213 \mathrm{~mm}(300 \times 300 \mathrm{DPI})$ 

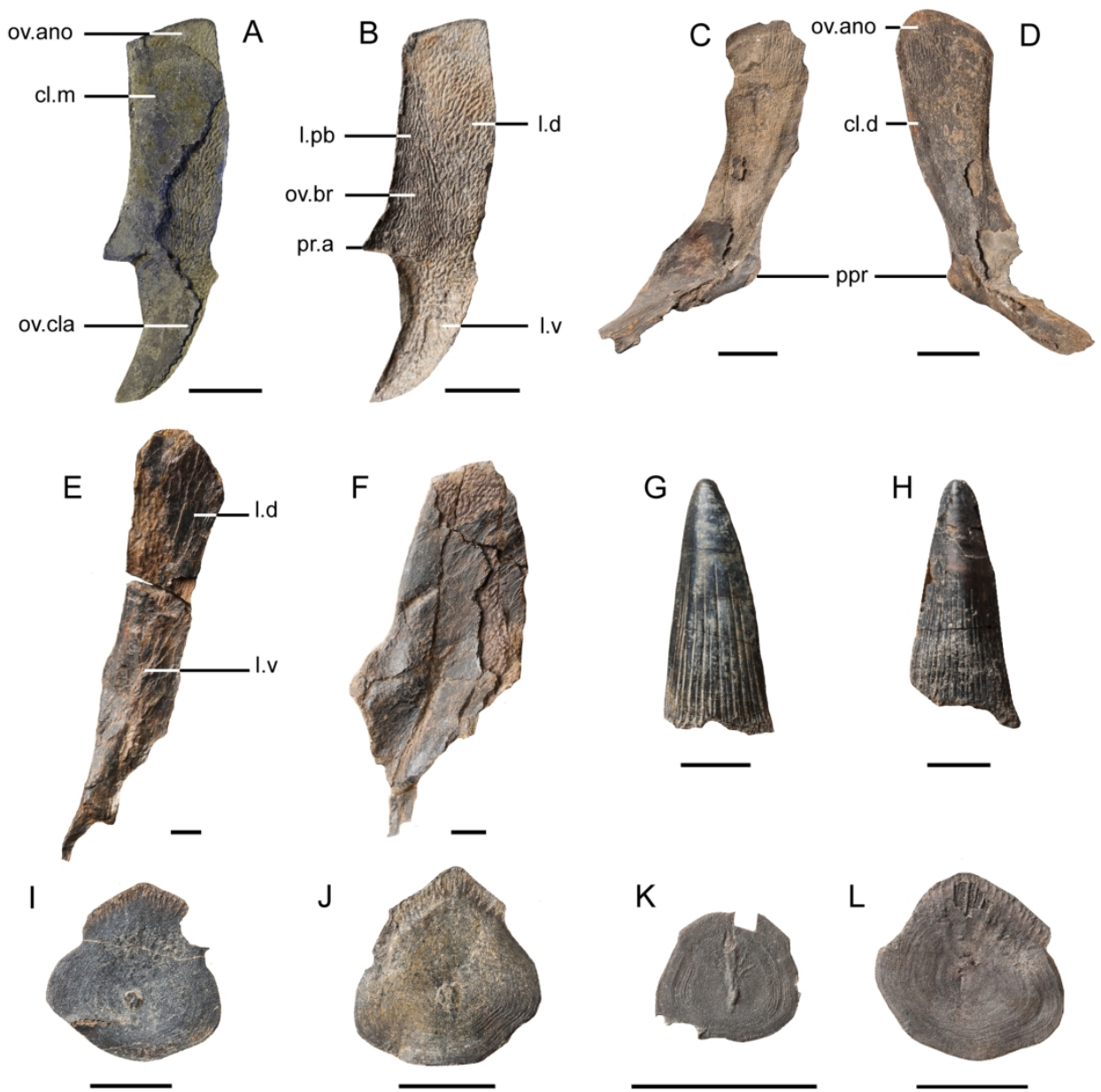

G

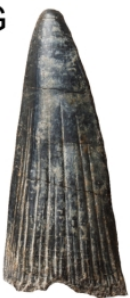

H

K

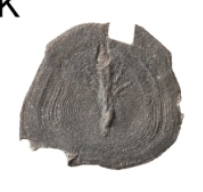

L

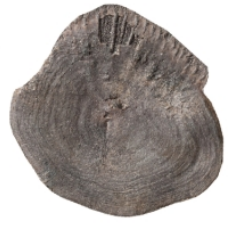

FIGURE 6. cf. Tristichopteridae indet., Strud, Belgium, Upper Famennian. A, right cleithrum, visceral view, IRSNB P 9924, photograph; B, right cleithrum, imprint of the external view (bone removed), IRSNB P 9924, photograph; C-D, right cleithrum, external and visceral views, IRSNB P 9925, photographs; E, incomplete right cleithrum, visceral view, IRSNB P 9926, photograph; F, incomplete right cleithrum, visceral view, IRSNB P 9927, photograph; G, isolated fang, labial or lingual view, IRSNB P 9928, photograph; $H$, isolated fang, labial or lingual view, IRSNB P 9929, photograph; I, isolated scale, visceral view, IRSNB P 9930, photograph; J, isolated scale, visceral view, IRSNB P 9931, photograph; K, isolated scale, visceral view, IRSNB P 9932, photograph; L, isolated scale, visceral view, IRSNB P 9933, photograph. Scale bars equal 1 $\mathrm{cm}$. [planned for page width]

$181 \times 178 \mathrm{~mm}(300 \times 300 \mathrm{DPI})$ 

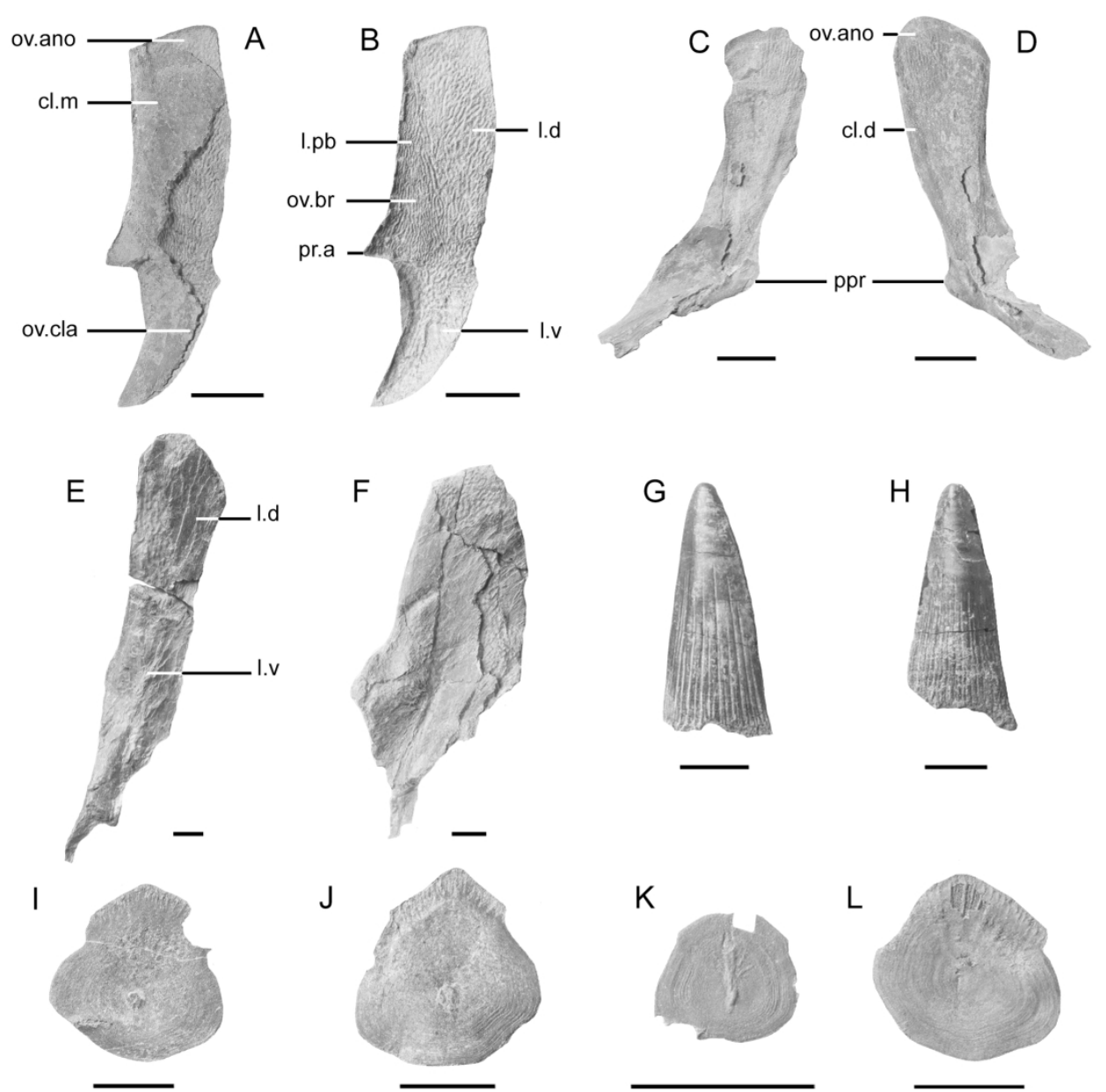

G

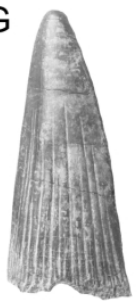

K

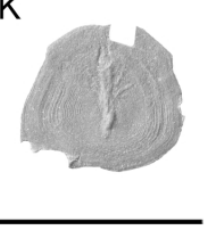

$\mathrm{H}$

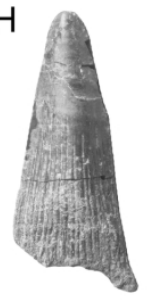

L

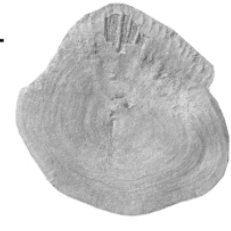

FIGURE 6. cf. Tristichopteridae indet., Strud, Belgium, Upper Famennian. A, right cleithrum, visceral view, IRSNB P 9924, photograph; B, right cleithrum, imprint of the external view (bone removed), IRSNB P 9924, photograph; C-D, right cleithrum, external and visceral views, IRSNB P 9925, photographs; E, incomplete right cleithrum, visceral view, IRSNB P 9926, photograph; F, incomplete right cleithrum, visceral view, IRSNB P 9927, photograph; G, isolated fang, labial or lingual view, IRSNB P 9928, photograph; $H$, isolated fang, labial or lingual view, IRSNB P 9929, photograph; I, isolated scale, visceral view, IRSNB P 9930, photograph; J, isolated scale, visceral view, IRSNB P 9931, photograph; K, isolated scale, visceral view, IRSNB P 9932, photograph; L, isolated scale, visceral view, IRSNB P 9933, photograph. Scale bars equal 1 $\mathrm{cm}$. [planned for page width]

$181 \times 178 \mathrm{~mm}(300 \times 300$ DPI) 
FIGURE 7. Strict consensus tree showing phylogenetic relationships of the Tristichopteridae, with maximum parsimony biogeographic reconstruction result using Bayesian Binary MCMC analysis mapped on. The number in the center of each pie chart corresponds to the node number. The pie chart over each node represents the probability that the clade originated from each continental area. The numbers on the top of each pie chart correspond to the Bremer index (in italics) and to the minimal and maximal number of synapomorphies at each node (in bold). Some character state changings have been reported on the branches. GIV for Givetian, FRAS for Frasnian and FAM for Famennian. [planned for page width]

$$
182 \times 193 \mathrm{~mm}(300 \times 300 \mathrm{DPI})
$$


FIGURE 7. Strict consensus tree showing phylogenetic relationships of the Tristichopteridae, with maximum parsimony biogeographic reconstruction result using Bayesian Binary MCMC analysis mapped on. The number in the center of each pie chart corresponds to the node number. The pie chart over each node represents the probability that the clade originated from each continental area. The numbers on the top of each pie chart correspond to the Bremer index (in italics) and to the minimal and maximal number of synapomorphies at each node (in bold). Some character state changings have been reported on the branches. GIV for Givetian, FRAS for Frasnian and FAM for Famennian. [planned for page width]

$$
182 \times 193 \mathrm{~mm}(300 \times 300 \mathrm{DPI})
$$

